\title{
The Neoproterozoic-early Paleozoic metamorphic and magmatic evolution of the Eastern Sierras Pampeanas: an overview
}

\author{
André Steenken • Mónica G. López de Luchi • \\ Carmen Martínez Dopico • Malte Drobe • \\ Klaus Wemmer $\cdot$ Siegfried Siegesmund
}

Received: 16 March 2010/Accepted: 20 November 2010/Published online: 30 December 2010

(c) Springer-Verlag 2010

\begin{abstract}
The Eastern Sierras Pampeanas were structured by three main events: the Ediacaran to early Cambrian (580-510 Ma) Pampean, the late Cambrian-Ordovician (500-440 Ma) Famatinian and the Devonian-Carboniferous (400-350 Ma) Achalian orogenies. Geochronological and $\mathrm{Sm}-\mathrm{Nd}$ isotopic evidence combined with petrological and structural features allow to speculate for a major rift event (Ediacaran) dividing into two Mesoproterozoic major crustal blocks (source of the Grenvillian age peaks in the metaclastic rocks).This event would be coeval with the development of arc magmatism along the eastern margin of the eastern block. Closure of this eastern margin led to a Cambrian active margin (Sierra Norte arc) along the western margin of the eastern block in which magmatism reworked the same crustal block. Consumption of a ridge segment (input of OIB signature mafic magmas) which controlled granulite-facies metamorphism led to a final collision (Pampean orogeny) with the western Mesoprotrozoic block. Sm-Nd results for the metamorphic basement suggest that the $T_{\mathrm{DM}}$ age interval of $1.8-1.7 \mathrm{Ga}$, which is associated with the less radiogenic values of
\end{abstract}

\section{A. Steenken}

Geologisches und Geographisches Institut,

Universität Greifswald, Friedrich-Ludwig-Jahn Strasse 17a,

17489 Greifswald, Germany

M. G. López de Luchi $(\bowtie)$ · C. Martínez Dopico

Instituto de Geocronología y Geología Isotópica (INGEIS), CONICET-Universidad de Buenos Aires,

Pabellón INGEIS, Ciudad Universitaria,

1428 Buenos Aires, Argentina

e-mail: deluchi@ingeis.uba.ar

M. Drobe $\cdot$ K. Wemmer $\cdot$ S. Siegesmund Geoscience Centre of the University of Göttingen, Goldschmidtstr. 3, 37077 Göttingen, Germany
${ }_{\varepsilon} \mathrm{Nd}_{(540)}(-6$ to -8$)$, can be considered as the mean average crustal composition for the Eastern Sierras Pampeanas. Increasing metamorphic grade in rocks with similar detrital sources and metamorphic ages like in the Sierras de Córdoba is associated with a younger $T_{\mathrm{DM}}$ age and a more positive $\varepsilon \mathrm{Nd}_{(540)}$ value. Pampean pre-540 Ma granitoids form two clusters, one with $T_{\mathrm{DM}}$ ages between 2.0 and $1.75 \mathrm{Ga}$ and another between 1.6 and $1.5 \mathrm{Ga}$. Pampean post-540 Ma granitoids exhibit more homogenous $T_{\mathrm{DM}}$ ages ranging from 2.0 to $1.75 \mathrm{Ga}$. Ordovician re-activation of active margin along the western part of the block that collided in the Cambrian led to arc magmatism (Famatinian orogeny) and related ensialic back-arc basin in which high-grade metamorphism is related to mid-crustal felsic plutonism and mafic magmatism with significant contamination of continental crust. $T_{\mathrm{DM}}$ values for the Ordovician Famatinian granitoids define a main interval of 1.8-1.6, except for the Ordovician TTG suites of the Sierras de Córdoba, which show younger $T_{\mathrm{DM}}$ ages ranging from 1.3 to $1.0 \mathrm{Ga}$. In Devonian times (Achalian orogeny), a new subduction regime installed west of the Eastern Sierras Pampeanas. Devonian magmatism in the Sierras exhibit process of mixing/assimilation of depleted mantle signature melts and continental crust. Achalian magmatism exhibits more radiogenic $\varepsilon \mathrm{Nd}_{(540)}$ values that range between 0.5 and -4 and $T_{\mathrm{DM}}$ ages younger than $1.3 \mathrm{Ga}$. In pre-Devonian times, crustal reworking is dominant, whereas processes during Devonian times involved different geochemical and isotopic signatures that reflect a major input of juvenile magmatism.

Keywords Magmatism-metamorphism . Sm-Nd systematics - Tectonic evolution . Neoproterozoic-early Paleozoic orogenies . Eastern Sierras Pampeanas 


\section{Introduction}

The Pacific margin of Gondwana is composed of different cratonic blocks that were amalgamated during several events from the Proterozoic to the Paleozoic (Rapela et al. 2007; Ramos 2008 and references therein). The Sierras Pampeanas, which constitute a series of $\mathrm{N}-\mathrm{S}$-oriented basement units cropping out between $26^{\circ}$ and $33^{\circ} \mathrm{S}$, are situated between the Archaean to Palaeoproterozoic Río de la Plata craton to the east against which they have a fault contact (López de Luchi et al. 2005) and to the Grenvillian Cuyania-Precordillera Terrane (Kay et al. 1996) in the west.

The Sierras Pampeanas are separated into the Eastern Sierras Pampeanas (ESP) dominated by Paleozoic granites, metasedimentary and metaigneous rocks, and the Western Sierras Pampeanas (WSP) characterized by metabasic, ultrabasic and calc-silicate rocks which expose Mesoproterozoic crystalline basement (Casquet et al. 2001, 2006; Vujovich et al. 2004).

The Eastern Sierras Pampeanas constitute polyphase deformed basement units, which were structured by three events: the Ediacaran to early Cambrian (580-510 Ma) Pampean, the late Cambrian-Ordovician (500-440 Ma) Famatinian and the Devonian-Carboniferous (400-350 Ma) Achalian orogenies (Aceñolaza and Toselli 1981; Rapela et al. 1998; Stuart-Smith et al. 1999; Steenken et al. 2006; López de Luchi et al. 2007; Drobe et al. 2009, 2010; Siegesmund et al. 2010). These orogenies are related to the accretion of different terranes integrated into the protoAndean margin of Gondwana. The low to high-grade metasedimentary successions of the Eastern Sierras Pampeanas were considered as an extension of the very low to low-grade Puncoviscana Formation (Drobe et al. 2009 and references therein) that is developed along the Cordillera Oriental.

The aim of this contribution is to give an overview of the geological features of the Eastern Sierras Pampeanas with the main focus on the Sierras de Córdoba, San Luis, and Chepes. We integrate available geological, geochemical, and isotopic information to set time constraints on the metamorphism and magmatism and to provide a summary of the data that may support a revised model for the late Neoproterozoic to early Paleozoic tectonic evolution of the proto-Andean margin of Gondwana. Hence, the paleotectonic scenario calls for a major rift event (Ediacaran) dividing crustal blocks with $\mathrm{Sm}-\mathrm{Nd}$ signature and producing juvenile crust with subsequent evolution of (Cambrian) active margins reworking the same crust. In the Ordovician, re-activation of active margins led to the opening of an ensialic back-arc basin with mafic crust production and significant contamination by continental crust. In Devonian times, a new subduction regime was installed west of the Eastern Sierras Pampeanas and magmatism involves a transient heat anomaly associated with extensive melting of an enriched mantle source and probably of a crustal segment.

\section{Geological background of the main basement units of the Eastern Sierras Pampeanas}

The Eastern Sierras Pampeanas extend from southern Salta to the San Luis and La Pampa provinces (Fig. 1). The eastern sector of these basement units is mainly affected by the Pampean orogeny, which is characterized by late Neoproterozoic sedimentation and Ediacaran to Cambrian deformation, magmatism and metamorphism (Rapela et al. 2007; Siegesmund et al. 2010). The western sector is dominated by the Famatinian orogeny, which is characterized by Cambrian marine sedimentation and late Cambrian to Ordovician magmatism (Sims et al. 1998; Steenken et al. 2006). The Achalian orogeny overprints this basement (Sims et al. 1998, Siegesmund et al. 2010). PostPampean cooling of the basement domains in the Cambrian to early Ordovician is related to imbrication and uplift along different shear zones, while middle to late Silurian $\mathrm{K} / \mathrm{Ar}$ biotite ages register different stages of the exhumation (Steenken et al. 2010).

\section{Sierras de Córdoba and Sierra Norte}

The Sierras de Córdoba and the Sierra Norte (Fig. 2), as well as its continuation in the Sierras de Ambargasta and Sumampa, are the easternmost group of the Sierras Pampeanas. These Sierras consists of a series of northsouth mountain chains limited by west-vergent reverse thrust faults on its western side and are separated by intermontane Mesozoic and Cenozoic sediments (Table 1).

The Sierra Norte, Sierras de Ambargasta and Sumampa, constitute a major block mostly made up of Ediacaran to early Cambrian arc-related I-type calc-alkaline granitoid intrusions named the Sierra Norte-Ambargasta Batholith (SNAB) (Lira et al. 1997; Siegesmund et al. 2010). Magmatic activity ceased in the late Cambrian with the emplacement of the Oncán porphyritic rhyolite dykes (Rapela et al. 1991; $494 \pm 11 \mathrm{Ma}$ ). The SNAB encloses large roof-pendants of a locally contact overprinted metamorphic complex (Table 1). The ages of these metamorphic rocks have been assigned to the late Precambrian (Siegesmund et al. 2010 and references therein).

The Sierras de Córdoba constitute a unit of igneous and low- to high-grade metamorphic para and orthogneisses, marble, amphibolites and ultramafic rocks, which underwent local partial melting processes that lead to migmatitization. Peraluminous and metaluminous granitoids of 
Fig. 1 Schematic map of the Early Paleozoic sequences of the Sierras Pampeanas,

Cordillera Oriental and Puna basement units (modified from Dalla Salda et al. 1998). Limits of the Pampean and Famatinian orogens were taken from Rapela et al. (2007)

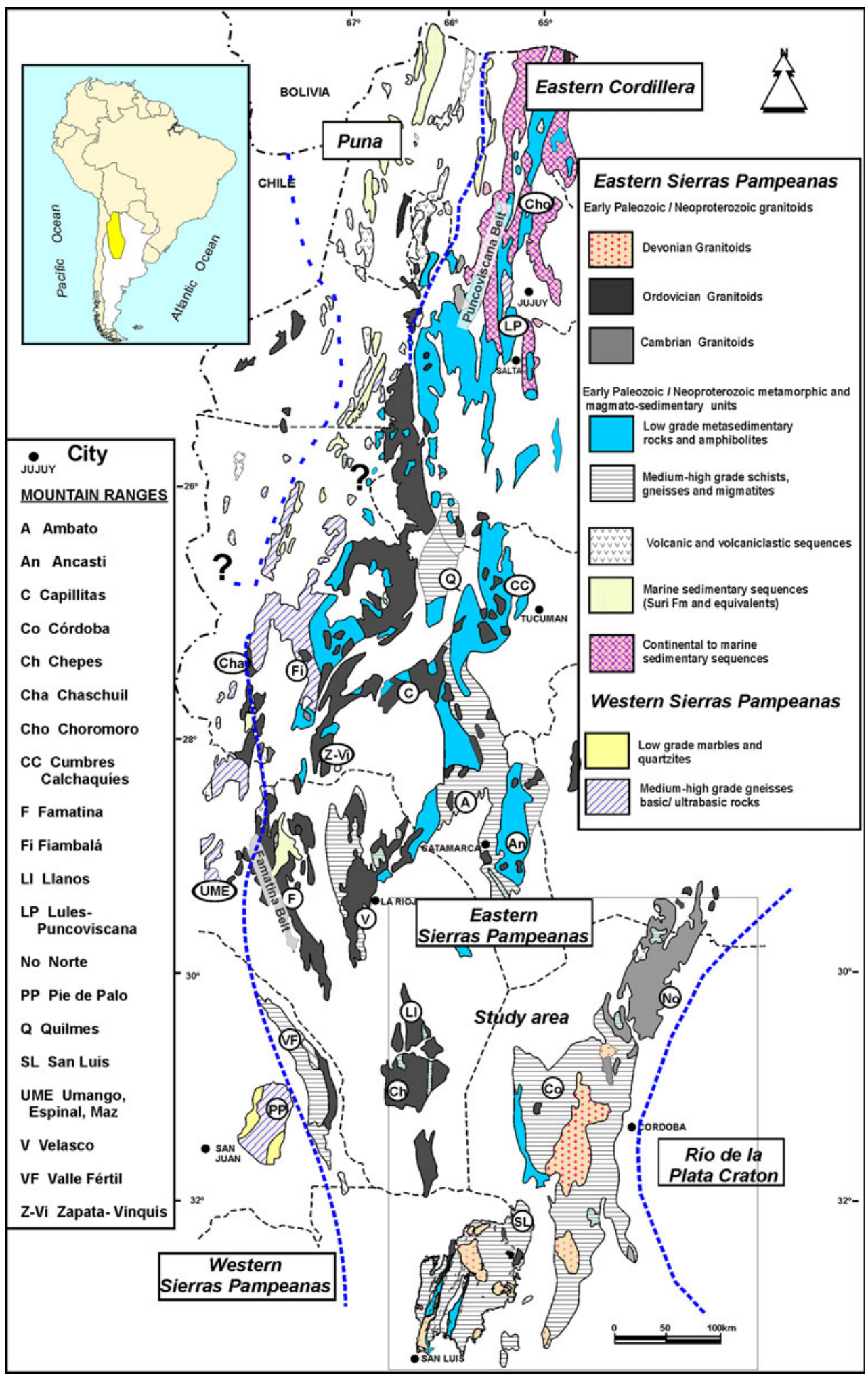

different ages intrude this basement (Rapela et al. 1998; Sims et al. 1998). The polymetamorphic complexes are organized in lithological and structural domains (Fig. 2): Sierra Chica, Sierra Grande and Sierra de Comechingones separated by ductile shear zones and mafic and ultramafic rocks (Siegesmund et al. 2010 and references therein). These domains are characterized by Ediacarian sedimentation and late Ediacaran to Cambrian deformation, 


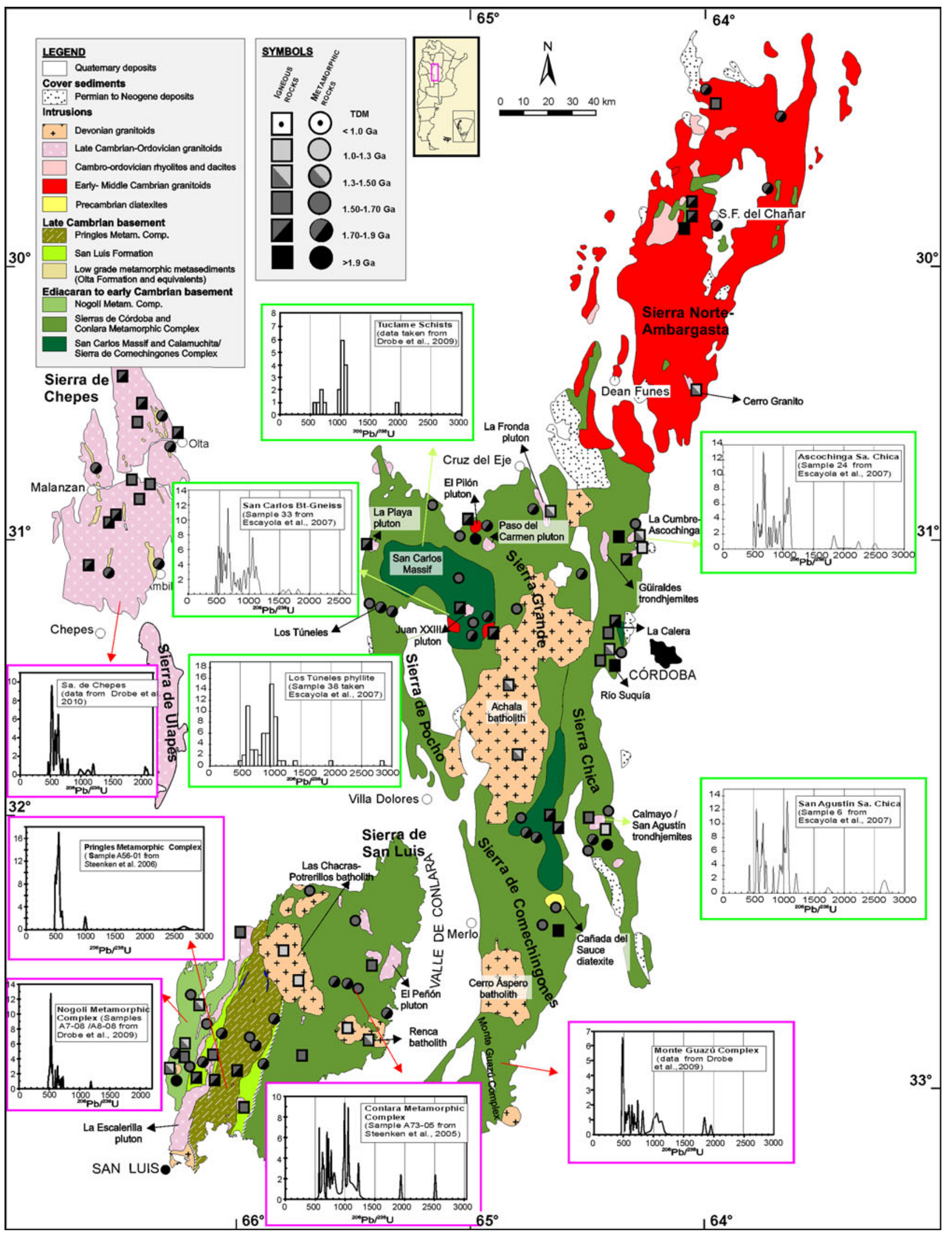


4 Fig. 2 Simplified geological map of the Sierras de Córdoba, the Sierra Norte, the Sierra de Chepes and the Sierra de San Luis (modified from Martino 2003; Steenken et al. 2006 and Siegesmund et al. 2010). Detrital zircon age spectra and $T_{\mathrm{DM}}$ ages for felsic igneous and metaclastic rocks are included

magmatism and metamorphism with a more restricted Ordovician magmatic event (Rapela et al. 1998; Siegesmund et al. 2010) and voluminous intrusions of Devonian granites. A NNW trending belt of granulite-facies metamorphic rocks and related S-Type granitoids (Fig. 2) can be split into the San Carlos Massif in the NW and to the SE into the Sierra de Comechingones (Guereschi and Martino 2008 and references therein). Mafic and ultramafic rocks that were in part interpreted as ophiolites were separated into an eastern belt called the Sierra Chica and a western belt known as the Sierra Grande (Mutti 1987; Escayola et al. 1996).

The Sierra Chica (Fig. 2) has been subdivided into a series of metamorphic complexes. Most southward, the Las Peñas metamorphic complex (Bonalumi et al. 2001) comprises medium- to high-grade metamorphic rocks (Table 1). In the central part, gneisses, homogenous and heterogeneous migmatites, marbles and amphibolites constitute the Sierra Chica Metamorphic Complex (Martino et al. 1995). In the north, partly migmatized gneisses with rare marble and amphibolite are present together with hornblende and biotite-bearing tonalite, granodiorite, biotite-bearing granite, granitic orthogneisses and banded paragneisses (Rapela et al. 1998).

The Sierra Grande is dominated by medium- to coarsegrained granitoid, K-feldspar-cordierite migmatites, anatectic granitoids and interlayered biotite gneisses and amphibolites of the San Carlos Massif (SCM; Bonalumi et al. 2001). This massif is limited to the east by quartz-rich micaceous gneisses and biotite-bearing quartz-feldspar gneisses that host marbles, amphibolites, and pegmatites. Toward the west, the SCM grades into gneisses and stromatic migmatites, which were overthrusted along the moderately inclined, NNW trending reverse Los Túneles shear belt (Martino 2003) onto phyllites (Mermela group). The deformation in the Los Túneles shear belt is constrained between the late Cambrian and the early Ordovician (Steenken et al. 2010). Guereschi and Martino (2008) proposed that a partial melting process related to the metamorphism $\left(\approx 700^{\circ} \mathrm{C}\right.$, 5.5-6.5 Kb) results from the exhumation after a compressional event. (Fig. 3). The Las Palmas gneiss located southwest of the SCM is a strongly folded high-grade banded gneiss (Gordillo 1984), which grades into cordierite-bearing diatexite, i.e. the Piedras Rosadas.

In the Sierra de Comechingones, three complexes (Otamendi et al. 1998, 2000; Sims et al. 1998) are distinguished: north of the Devonian Cerro Aspero batholith
(Fig. 2) the Sierra de Comechingones Metamorphic Complex (SCMC) and to the south, the Monte Guazú and the Achiras complexes (Table 1). The SCMC consists of a medium- to high-grade metasedimentary sequence, peraluminous leucogranites, marble/calc-silicate, gabbros, amphibolite with MORB-like affinities and mafic-ultramafic rocks (Otamendi et al. 2004 and references therein). Martino et al. (1995) separated the SCMC into the cordierite-bearing diatexites and stromatic migmatites of the Yacanto group. The locally interlayered San Miguel group is composed of mafic and ultramafic rocks, garnet-bearing gneisses and marbles and the Santa Rosa cordierite-garnet granulite. The mafic rocks also appear widespread as small intrusive dikes and as pillows in the migmatites (Otamendi et al. 2004). The Monte Guazú Complex is distinguished by having a probably Ordovician (Gromet et al. 2001; Drobe et al. 2010 this volume) suite of intermediate calcalkaline igneous rocks interlayered with medium- to high-grade metasedimentary rocks (Fagiano et al. 2008; Otamendi et al. 2000). The Achiras Complex is a monotonous sequence comprising discontinuous belts of greywacke-derived amphibolite-facies gneisses and schists that are interlayered with peraluminous leucogranites. The complex is intruded by Devonian peraluminous granites, like the Achiras granite $(384 \pm 6 \mathrm{Ma}, \mathrm{U}-\mathrm{Pb}$ zircon, StuartSmith et al. 1999). Fagiano et al. (2008) proposed an Ordovician age for the metamorphism of the Achiras Complex (Table 1). The Achiras Metamorphic Complex was correlated with the Conlara Metamorphic Complex (Sims et al. 1998).

The aforementioned metamorphic complexes affected the moderately east-dipping, N-S trending early Cambrian to Silurian Guacha Corral shear belt (Martino 2003; Steenken et al. 2010; Fig. 2), which juxtaposed the basement of the Sierra de Comechingones on top of the eastern slope of the Sierra de San Luis, i.e. the Conlara Metamorphic Complex.

\section{Sierra de San Luis}

The Sierra de San Luis (Figs. 1, 2) records an Ediacaran to Devonian metamorphic and magmatic evolution and comprises three NNE-SSW striking basement domains of amphibolite- to granulite-facies complexes, the Nogolí, Pringles and Conlara metamorphic complexes (Sims et al. 1997). The domains are generally (Fig. 2) separated by an assemblage of metaquartz arenites and phyllites: the San Luis Formation (Prozzi and Ramos 1988) and are intruded by Ordovician and Devonian granitoids (Sims et al. 1997, 1998; López de Luchi et al. 2007). The metamorphic events and mineral parageneses are summarized in Table 1.

The Conlara Metamorphic Complex (CMC) is the easternmost of these complexes. The western margin of the 
Table 1 Mineral paragenesis, P-T constraints and ages of the Pampean and Famatinian metamorphic events

\begin{tabular}{|c|c|c|c|c|c|}
\hline & & Lithology & PT conditions & Age & References \\
\hline \multicolumn{6}{|l|}{ Sierras de Córdoba } \\
\hline \multicolumn{6}{|l|}{ Sierra Norte } \\
\hline Roof pendants in SNAB & M1 & $\begin{array}{l}\text { Low-grade slates and schists; } \\
\text { medium-grade amphibolites } \\
\text { and marbles; high-grade } \\
\text { gneisses and migmatites }\end{array}$ & & $584-560 \mathrm{Ma}$ & Llambías et al. (2003) \\
\hline \multicolumn{6}{|l|}{ Sierra Chica } \\
\hline Las Peñas MC & M2? & $\begin{array}{l}\text { Orthogneisses; metabasic rocks, } \\
\text { amphibolites, impure marbles, } \\
\text { Grt + Cdr + Kfs migmatites }\end{array}$ & & & Bonalumi et al. (2001) \\
\hline \multirow[t]{2}{*}{ Sierra Chica MC } & M2? & Sill + Cdr + Grt migmatites & $\begin{array}{l}6-6.5 \mathrm{Kbar} \\
700-750^{\circ} \mathrm{C}\end{array}$ & & Martino et al. (1995) \\
\hline & & $\begin{array}{l}\text { Amphibolites, marbles, Grt }+\mathrm{Bt} \\
\text { gneisses }\end{array}$ & & & Gordillo (1984) \\
\hline \multirow[t]{2}{*}{ La Calera Group } & M2 & Metabasic rocks & $9 \mathrm{Kbar} 810^{\circ} \mathrm{C}$ & $522 \pm 8$ Ma mon & Rapela et al. (1998) \\
\hline & & Crd + Grt Diatexites & $6 \mathrm{Kbar} 820^{\circ} \mathrm{C}$ & & Baldo et al. (1996) \\
\hline \multirow[t]{2}{*}{ San Roque MC } & M2? & Ms + Sill gneisses, Bt gneisses & & & Rapela et al. (1998) \\
\hline & & Ti-rich amphibolites & & & Baldo et al. (1996) \\
\hline \multirow[t]{4}{*}{ El Diquecito Group } & & Tonalitic orthogneisses & & & Rapela et al. (1998) \\
\hline & & Sill + Grt + Kfs gneisses & & & Baldo et al. (1996) \\
\hline & & $\begin{array}{l}\text { Marbles; diopside-rich } \\
\text { amphibolites }\end{array}$ & & & \\
\hline & M2 & Crd migmatites & $6 \mathrm{Kbar} 820^{\circ} \mathrm{C}$ & $522 \pm 8$ Ma mon & \\
\hline Ascochinga Complex & M2? & Banded paragneisses & & & Rapela et al. (1998) \\
\hline \multicolumn{6}{|l|}{ Sierra Grande } \\
\hline \multirow[t]{2}{*}{ San Carlos Massif } & M2 & Crd + Sill migmatites & $5.5-6.5 \mathrm{Kbar} 700^{\circ} \mathrm{C}$ & $\begin{array}{l}\text { Ca.530 Ma Peak at } \\
\text { 500-560 Ma }\end{array}$ & $\begin{array}{l}\text { Guereschi and Martino } \\
\text { (2008) }\end{array}$ \\
\hline & & Bt gneisses & & & Escayola et al. (2007) \\
\hline Las Palmas & M1 & $\begin{array}{l}\text { Grt }+ \text { Sill }+(\mathrm{Kfs}+\mathrm{Bt}) \text { banded } \\
\text { gneisses }\end{array}$ & & $543 \pm 4 \mathrm{Ma}$ & $\begin{array}{l}\text { Gordillo (1984); Siegesmund } \\
\text { et al. (2010) }\end{array}$ \\
\hline \multirow[t]{2}{*}{ Pichanas Complex } & M2 & Grt gneiss & Low $\mathrm{P}$ high $\mathrm{T}$ & $531 \pm 10 \mathrm{Ma}$ & Sims et al. (1998) \\
\hline & M1 & & & $561 \pm 10 \mathrm{Ma}$ & \\
\hline Los Túneles & & Phyllite & $250-280^{\circ} \mathrm{C}$ & $\begin{array}{l}\text { Detrital peak at } \\
600 \mathrm{Ma}\end{array}$ & Escayola et al. (2007) \\
\hline North Achala & & Crd gneisses & $4.5 \mathrm{Kbar} 685^{\circ} \mathrm{C}$ & & Baldo et al. (1996) \\
\hline \multirow[t]{2}{*}{ Quilpo Fm } & M2 & Crd + Sill + Grt gneiss & & $529 \pm 10 \mathrm{Ma}$ & Sims et al. (1998) \\
\hline & M1 & Bt-Grt gneiss & & $581 \pm 16 \mathrm{Ma}$ & \\
\hline \multicolumn{6}{|l|}{ Sierras de Córdoba } \\
\hline \multicolumn{6}{|l|}{ Sierra de Comechingones } \\
\hline \multicolumn{6}{|l|}{ Sierra de Comechingones MC } \\
\hline \multirow[t]{2}{*}{ Cañada del Sauce } & M1 & Bt-Grt-Crd-Kfs diatexite & $\begin{array}{l}5.5-6 \mathrm{Kbar} \\
725-780^{\circ} \mathrm{C}\end{array}$ & $577 \pm 11 \mathrm{Ma}$ & Siegesmund et al. (2010) \\
\hline & & & & & $\begin{array}{l}\text { Guereschi and Martino } \\
\text { (2008) }\end{array}$ \\
\hline Tala Cruz & M1 & $\begin{array}{l}\mathrm{Bt}+\mathrm{Sill}+\mathrm{Grt}+\mathrm{Kfs} \\
\quad \text { Stromatite }\end{array}$ & $\begin{array}{l}8.5-9 \mathrm{Kbar} \\
810-840^{\circ} \mathrm{C}\end{array}$ & $553 \pm 3 \mathrm{Ma}$ & $\begin{array}{l}\text { Guereschi and Martino } \\
\text { (2008) }\end{array}$ \\
\hline \multirow{2}{*}{$\begin{array}{l}\text { Sierra de Comechingones } \\
\text { MC }\end{array}$} & & Gneiss, diatexites & & & \\
\hline & & Amphibolites and peridotites & & & Otamendi et al. (2004) \\
\hline \multirow[t]{2}{*}{ Santa Rosa Massif } & M2 & Crd migmatites & $7.5 \mathrm{Kbar} 850-900^{\circ} \mathrm{C}$ & $536 \pm 11 \mathrm{Ma}$ & Otamendi et al. (2006) \\
\hline & & & & $511 \pm 6 \mathrm{Ma}$ & Siegesmund et al. (2010) \\
\hline \multirow[t]{2}{*}{ Monte Guazú Complex } & M2 & $\begin{array}{l}\text { Kfs }+ \text { Sill }+ \text { Grt stromatitic } \\
\text { migmatite }\end{array}$ & $7 \mathrm{Kbar} 750^{\circ} \mathrm{C}$ & & Fagiano et al. (2008) \\
\hline & M1 & $\mathrm{Pl}+\mathrm{Qz}+\mathrm{Bt} \pm$ Grt paragneiss & & & \\
\hline
\end{tabular}


Table 1 continued

\begin{tabular}{|c|c|c|c|c|c|}
\hline & & Lithology & PT conditions & Age & References \\
\hline \multirow[t]{2}{*}{ Achiras MC } & M1 & $\mathrm{Grt}+\mathrm{Bt}+\mathrm{Pl}+\mathrm{Qtz}$ schist & $<5$ Kbar $420-530^{\circ} \mathrm{C}$ & & Fagiano et al. (2008) \\
\hline & M2 & & $5-8 \mathrm{Kbar} 760^{\circ} \mathrm{C}$ & & Otamendi et al. (2004) \\
\hline \multicolumn{6}{|l|}{ Sierra de San Luis } \\
\hline \multirow[t]{3}{*}{ Pringles MC } & $\begin{array}{l}\text { M1/ } \\
\text { M2 }\end{array}$ & $\begin{array}{l}\text { Pl-Kfs-Grt-Bt-Sill } \pm \text { Crd } \\
\text { granulite }\end{array}$ & $\begin{array}{r}5.7-6.4 \mathrm{Kbar} \\
740-790^{\circ} \mathrm{C}\end{array}$ & $498 \pm 10 \mathrm{Ma}$ & Steenken et al. (2006) \\
\hline & & $\begin{array}{l}\mathrm{Chl}+\mathrm{Bt}+\mathrm{Ms}+\mathrm{Qtz}+\mathrm{Pl}+ \\
\text { Kfs amphibolite }\end{array}$ & & & \\
\hline & & $\begin{array}{l}\text { Micaschists, migmatites and } \\
\text { amphibolites }\end{array}$ & & & Hauzenberger et al. (2001) \\
\hline \multirow[t]{2}{*}{ Nogolí MC } & M2? & $\begin{array}{l}\text { Bt }+ \text { Sill }+ \text { Pl migmatite; } \\
\text { micaschists, metaquartzites, } \\
\text { migmatites and amphibolites; } \\
\text { metabasalts }\end{array}$ & & $478 \pm 4 \mathrm{Ma}$ & Steenken et al. (2006) \\
\hline & & Bt-Pl-Grt gneiss & $5-8 \mathrm{Kbar} 660-791^{\circ} \mathrm{C}$ & & González et al. (2009 \\
\hline San Luis Fm & M1 & $\begin{array}{l}\mathrm{Ill}+\mathrm{Chl}+\mathrm{Bt}+\mathrm{Qtz} \pm \mathrm{Ab} \pm \\
\text { Grt phyllite }\end{array}$ & $250-350^{\circ} \mathrm{C}$ & $\begin{array}{l}\text { Post } 530-\text { pre ca } \\
480 \mathrm{Ma}\end{array}$ & Drobe et al. (2009) \\
\hline \multirow[t]{2}{*}{ Conlara MC } & M2 & $\begin{array}{l}\mathrm{Bt}+\mathrm{Qtz}+\mathrm{Pl} \pm \text { Grt banded } \\
\text { schist }\end{array}$ & $\backsim 5 \mathrm{Kbar} \backsim 600^{\circ} \mathrm{C}$ & $564 \pm 21 \mathrm{Ma}$ & Siegesmund et al. (2010) \\
\hline & & $\begin{array}{l}\text { Metagreywackes, metapelites, } \\
\text { turmaline schist }\end{array}$ & & $\begin{array}{l}\text { Detrital } \\
\text { ages }<560 \mathrm{Ma}\end{array}$ & \\
\hline \multicolumn{6}{|l|}{ Sierra de Chepes } \\
\hline \multirow[t]{3}{*}{ Roof pendants in granitoids } & M2 & Low-medium grade metapelites & & & \\
\hline & & Bt to $\mathrm{Crd}$ zones & $3 \mathrm{Kbar} 400-700^{\circ} \mathrm{C}$ & $478 \pm 9 \mathrm{Ma}$ & Pankhurst et al. (1998) \\
\hline & & Migmatites (And-Kfs zone) & & & \\
\hline \multicolumn{6}{|l|}{ Sierra de Velazco } \\
\hline & & Phyllites (Bt zone) & & & $\begin{array}{l}\text { Toselli (1990), Rapela et al. } \\
\text { (2001),Toselli et al. (2005) }\end{array}$ \\
\hline & & $\begin{array}{l}\text { Micaschists, metaquarzites (And } \\
\text { zone) }\end{array}$ & & & \\
\hline & & Crd migmatites (Sill-Kfs zone) & & & \\
\hline & & Antinaco orthogneiss & 5-7 Kbar $600^{\circ} \mathrm{C}$ & $471 \pm 3 \mathrm{Ma}$ & \\
\hline \multicolumn{6}{|l|}{ Sierra de Ancasti } \\
\hline \multicolumn{6}{|l|}{ West } \\
\hline Ancasti Fm. & & Metasediments & & & Willner (1983) \\
\hline \multirow[t]{2}{*}{ Portezuelo Fm. } & & $\begin{array}{l}\mathrm{Crd}+\mathrm{Bt}+\mathrm{Sill}+\mathrm{Kfs} \pm \mathrm{Grt} \\
\text { Gneisses }\end{array}$ & & & \\
\hline & M2 & $\begin{array}{l}\mathrm{Qtz}+\mathrm{Pl}+\mathrm{Kfs}+\mathrm{Bt}+\mathrm{Grt} \\
\quad \text { Migmatites }\end{array}$ & & ca.472 Ma & \\
\hline \multicolumn{6}{|l|}{ Cent. } \\
\hline \multirow[t]{2}{*}{ Ancasti Fm. } & & Folded banded schists & & & \\
\hline & M1 & $\mathrm{Bt}+\mathrm{Pl} \pm \mathrm{Grt} \pm \mathrm{Ms}$ schists & Low $\mathrm{P}$ & $524 \pm 28$ & $\begin{array}{l}\text { Knüver (1983); Willner } \\
\text { (1983) }\end{array}$ \\
\hline \multicolumn{6}{|l|}{ East } \\
\hline \multicolumn{2}{|l|}{ Jumeal Mb of Sierra Brava C. } & Paragneisses, migmatites & & & Aceñolaza and Toselli (1977) \\
\hline \multicolumn{2}{|l|}{$\begin{array}{l}\text { La Calera Mb of Sierra Brava } \\
\text { C. }\end{array}$} & $\begin{array}{l}\text { Marbles, schists, and } \\
\text { amphibolites }\end{array}$ & & & \\
\hline \multicolumn{6}{|l|}{ Sierra de Quilmes } \\
\hline \multicolumn{6}{|l|}{ SW } \\
\hline Met-equiv. & & Amphibolite-facies rocks & & ca.470 Ma & Büttner et al. (2005) \\
\hline Puncoviscana Fm. & & Migmatites & & ca.6 kbar $800^{\circ} \mathrm{C}$ & \\
\hline NE & & $\begin{array}{l}\text { Very low-grade clastic } \\
\text { metasedimentary rocks }\end{array}$ & & & \\
\hline
\end{tabular}

M1 and M2 refer to the stages of metamorphism as described in the cited articles. These labels are not used in the text 


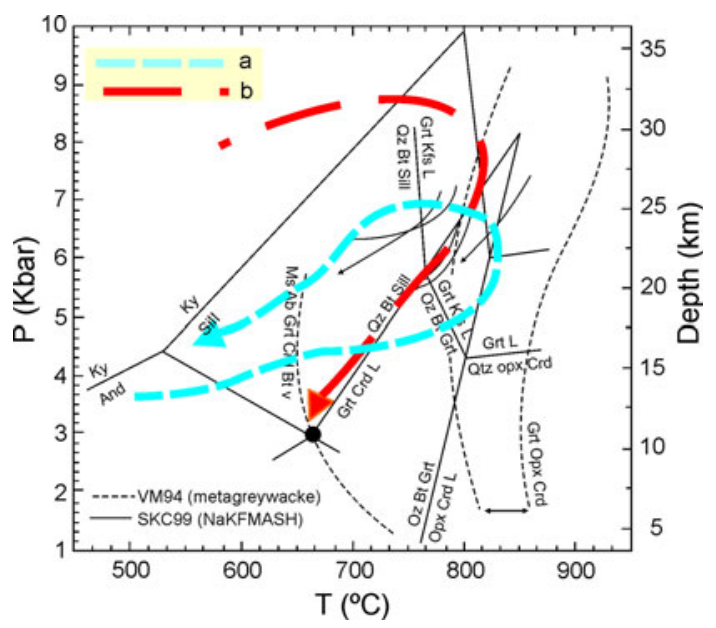

Fig. 3 P-T path for high-grade metamorphic rocks of the Sierra de Comechingones and the Pringles Metamorphic Complex. $a \mathrm{P}-\mathrm{T}$ path for the Pringles Metamorphic Complex taken from Delpino et al. (2007) and $b$ the P-T path for the Sierra de Comechingones after Guereschi and Martino (2008). Note that the trajectories are different for the Sierra de Comechingones and the Pringles Metamorphic Complex. In the former, higher grade reactions are crossed before decompression; whereas in the latter, these reactions pre-dated an isothermal compression path. Compilation of reactions by Otamendi et al. (2004) according to VM94 (Vielzeuf and Montel 1994) and SKC99 (Spear et al. 1999). Mineral abbreviations after Kretz (1983)

CMC is affected by the Devonian Río Guzmán shear zone, whereas its eastern margin toward the Sierra de Comechingones (Sims et al. 1997) is controlled by the Guacha Corral shear zone. The metamorphic series of the CMC comprises NNE trending metagreywackes and scarce metapelites and metaigneous components, which encompass basic sills and granitic rocks. These belong to two distinct groups: an earlier one represented by orthogneisses, locally migmatites, mainly tonalitic to granodioritic and scarce amphibolites and a later granitic one, which comprises late Cambrian to early Ordovician monzogranite to tonalitic plutons (i.e. La Tapera, El Peñón, El Salado) and a group of large granitic pegmatites.

The Nogoli Metamorphic Complex (NMC) is composed of paragneisses, mica schists, metaquartzites, and migmatites, with minor amphibolite and small lenses of two micas and garnet leucogranites. González et al. (2009 and references therein) proposed that part of the amphibolites are meta-komatiites, and high-Fe tholeiite metabasalts, which are interlayered with marbles and banded iron formation. $\mathrm{W}$ to NW trending remnants were considered as preFamatinian (Pampean?), whereas NNE to NE trending penetrative deformation were related to the Famatinian deformation (González et al. 2004). Prograde regional metamorphism accompanies deformational phases, from at least middle greenschist to high amphibolite facies.

The Pringles Metamorphic Complex (PMC) consists of paragneisses, mica schists, migmatites, and amphibolites.
Discontinuous lenses of mafic (mainly norites) to ultramafic units occur along a narrow NNE-SSW central belt concordant with the NNE-trending S2 foliation. Granulite-facies metamorphism, which would result from the emplacement of (ultra-) mafic intrusions, occurred during the beginning of the Famatinian cycle (Fig. 3; Hauzenberger et al. 2001; Steenken et al. 2005, 2006; Delpino et al. 2007). Granulitefacies assemblages grade into amphibolite and greenschist facies assemblages (Hauzenberger et al. 2001; Delpino et al. 2007).

The NNE trending low-grade phyllites and metaquartz-arenites of the San Luis Formation appears in two belts (Fig. 2). NNE trending large-scale tight folds with a moderate plunge is the main deformation style in the San Luis Formation, corresponding to the Famatinian event recorded in the PMC (Steenken et al. 2006, 2008). Isoclinally folded quartz layers within the phyllites (Fig. 2) suggest a preceding deformation phase. The transpressional Río Guzmán shear zone that accommodated the "east-sideup" displacement of the CMC is developed along the eastern belt of this formation (Steenken et al. 2008).

\section{Sierra de Chepes}

The Sierras de Chepes, Malanzán, and Los Llanos (Fig. 2) are composed of early Ordovician metaluminous, calcalkaline granitoids, and restricted peraluminous S-type monzogranites. Small bodies of gabbro diorite or quartz diorite frequently mingled with the surrounding granodiorites. The most important granitoid unit is the $490 \pm$ $5 \mathrm{Ma}(\mathrm{U} / \mathrm{Pb}$ zircon age) Chepes Granodiorite (Pankhurst et al. 1998). The metasedimentary rocks in the Sierras de Chepes occur as discontinuous roof pendants of the host (Pankhurst et al. 1998). These greenschist to amphibolite grade rocks are largely metapelites with intercalations of metarenites. A first metamorphism is represented by finegrained inclusions of biotite, magnetite, quartz, and muscovite preserved in cordierite porphyroblasts. The second, but low-pressure metamorphism, which was considered as coeval with the granitoid emplacement (Pankhurst et al. 1998), grades from phyllite to an anatectic zone (Pankhurst et al. 1998). The metamorphic events and mineral parageneses are summarized in Table 1.

\section{Main geological features of other basement blocks in the Eastern Sierras Pampeanas}

The Sierra de Quilmes metamorphic complex (Fig. 1) consists of upper to mid-crustal, mainly siliciclastic metasediments and shows a continuous, northeast to southwest transition from very low- and low-grade metamorphic clastic sediments into amphibolite facies and migmatitic 
rocks (Table 1). The protoliths were mainly turbiditic sediments of the Puncoviscana Formation (Toselli 1990; Toselli and Rossi de Toselli 1990). Büttner et al. (2005) calculated an Ordovician age for the metamorphic peak.

The Sierra de Velasco (Fig. 1) is dominated by granitoids. Low-grade metamorphic rocks (Table 1) are only present as small outcrops along the eastern flank. These phyllites and mica schists have been correlated with the lower Ordovician metasedimentary La Cébila Formation (Verdecchia et al. 2007; Grosse et al. 2008), which separates the Sierra de Velasco from the Sierra de Ambato (Fig. 1).

The Sierra de Ancasti (Fig. 1) comprises three metamorphic domains. The eastern flank, the Sierra Brava Complex is composed of paragneisses and migmatites (Aceñolaza and Toselli 1981) as well as marbles, schists, and amphibolites. The central sector is mostly formed by folded NNW-SSE trending banded schist of the Ancasti Formation (Aceñolaza and Toselli 1981; Willner 1983), which records a low-pressure Pampean metamorphism that was overprinted by a syn-deformational medium-grade event (Willner 1983; Knüver 1983; Gaido 2003). In the western flank, metasediments of the Ancasti Formation prograde into gneiss and migmatites of the El Portezuelo Formation (Willner 1983). Ordovician granites and tourmaline- and beryl-bearing pegmatites are emplaced in the Sierra Brava Complex and the Ancasti Formation. The metamorphic events and mineral parageneses are summarized in Table 1.

\section{Time constraints for the Pampean metamorphism}

Time constraints for the sedimentation of the clastic units that later constituted the Pampean metamorphic basement of the Eastern Sierras Pampeanas are provided by detrital zircon ages of the different units of the Sierras de Córdoba, the CMC (Fig. 2) and the Ancasti Formation. In the Sierras de Córdoba, younger detrital zircons are around $550 \mathrm{Ma}$ as well as in the Conlara Metamorphic Complex (Steenken et al. 2008; Siegesmund et al. 2010). In the Sierra de Ancasti, the youngest detrital peak is ca. 570 Ma (Rapela et al. 2007).

In the Sierra Norte, age constraints for the metamorphic evolution predating the emplacement of the SNAB granitoids are provided by two ages. First, the $584 \mathrm{Ma}$ age of an ignimbritic rhyolite (Llambías et al. 2003) which is interlayered with a metaclastic gneiss, and secondly, the $\mathrm{U} / \mathrm{Pb}$ age of $533 \pm 12 \mathrm{Ma}$ for the San Miguel orthogneiss located along the eastern flank of the Sierra de Sumampa (Siegesmund et al. 2010).

Rapela et al. (1998, 2002) and Otamendi et al. (2006) related the main Pampean migmatization event, cordierite formation and metamorphic peak at $\sim 530 \mathrm{Ma}$ in the Sierra Grande and in the Sierra de Comechingones to a second phase of metamorphism. In the Sierra Grande, the $\mathrm{U} / \mathrm{Pb}$ zircon age of $543 \pm 3.6 \mathrm{Ma}$ for the high-grade nonmigmatitic Las Palmas gneiss (Fig. 2) (Siegesmund et al. 2010) suggests an earlier onset of metamorphism than widespread anatexis at $\sim 530 \mathrm{Ma}$. In the Sierra de Comechingones Metamorphic Complex, the Tala Cruz migmatites yielded a concordant SHRIMP U/Pb zircon age of $553.5 \pm 3.2 \mathrm{Ma}$ (Siegesmund et al. 2010), whereas the Cañada del Sauce diatexite (Guereschi and Martino 2008) yielded an older metamorphic event of $577 \pm 11 \mathrm{Ma}$ (Siegesmund et al. 2010). Therefore, portions of the basement of the Sierra de Comechingones might be older than Late Ediacaran and the ubiquitous metamorphic equivalents of the Puncoviscana Formation. The Santa Rosa Grt-Crd granulite, i.e. the restite of the melting event related with the second phase of metamorphism, yielded a $\mathrm{U} / \mathrm{Pb}$ zircon age of $536 \pm 11 \mathrm{Ma}$ (Siegesmund et al. 2010).

Constraints on the younger limit of the metamorphism are provided by $\mathrm{PbSL}$ titanite ages obtained from calcsilicate intercalations in the San Carlos Massif, which yielded an age of $505.7 \pm 7.3 \mathrm{Ma}$ (Siegesmund et al. 2010). K/Ar and $\mathrm{Ar} / \mathrm{Ar}$ muscovite ages starting at $502 \mathrm{Ma}$ were reported by Krol and Simpson (1999) and Steenken et al. (2010). These ages mark the end of the Pampean metamorphism and may suggest a relatively fast exhumation of the Pampean orogen at $\sim 500 \mathrm{Ma}$. This event correlates with the first activation of the Guacha Corral and Los Túneles shear zones (Steenken et al. 2010), the initiation of renewed compression along the Gondwana margin (Steenken et al. 2006 and references therein) and with the Irúyica deformation phase (Astini et al. 2008), an early phase of the Famatinian orogeny.

Evidence that the Pampean orogeny started in the Ediacaran is also provided by the $\mathrm{Pb} / \mathrm{Pb}$ garnet age of $564 \pm 21 \mathrm{Ma}$ (Siegesmund et al. 2010) for the banded schist of CMC. In the Sierra de Ancasti, detrital zircons of the Ancasti Formation (Rapela et al. 2007) indicate that the sedimentation should be youngest than 600-570 Ma. The main tectonothermal event affecting these rocks is assigned to the Pampean orogeny based on the $\mathrm{Rb}-\mathrm{Sr}$ mineral isochron of $524 \pm 28 \mathrm{Ma}$ (Knüver 1983). In Table 1, ages and P-T-t constraints of the Pampean metamorphic events are summarized.

\section{Time constraints for the Famatinian metamorphism}

Ordovician Famatinian metamorphism is mostly related to the closure of ensialic back-arc or inter-arc basins developed east (in the ESP) or inside the main Famatina magmatic arc in the Sierra de Famatina (Balhburg 1991; 
Steenken et al. 2006; Dahlquist et al. 2008; Collo et al. 2009; Drobe et al. 2010 this volume). In the latter (Fig. 1), low-grade metamorphism and deformation are bracketed between $457 \pm 9$ and $463 \pm 14 \mathrm{Ma}$ (Collo et al. 2008). The youngest detrital zircon ages exhibit a major peak at $486 \pm 5 \mathrm{Ma}$ and possibly a younger one at $463 \pm 7 \mathrm{Ma}$, which suggests a derivation from the active Famatinian arc (Dahlquist et al. 2008).

SHRIMP and PbSL analysis indicate a concordant $\mathrm{U} / \mathrm{Pb}$ age at $498 \pm 10 \mathrm{Ma}$ for granulite-facies metamorphism of the Pringles Metamorphic Complex (Steenken et al. 2006, 2008). $\mathrm{Pb} / \mathrm{Pb}$ garnet ages indicate that the $\mathrm{Pb}$ isotope equilibration took place during the middle to late Ordovician (452 $\pm 19 \mathrm{Ma})$, defining the youngest age of the metamorphism. Post-dating the onset of high-grade metamorphism, the Pringles Metamorphic Complex was intruded by ca. $490 \mathrm{Ma}$ granitoids (Steenken et al. 2006). At around 478-468 Ma, granodioritic to tonalitic rocks intrude the low-grade San Luis Formation post-dating the onset of the first metamorphic overprint (Steenken et al. 2006).

A pre-Famatinian deformational and metamorphic history for the Nogolí Metamorphic Complex was proposed by von Gosen and Prozzi (1998), Sato et al. (2003) and González et al. (2004, 2009). The banded iron formation and mafic to ultramafic meta-volcanic rocks should be of Mesoproterozoic age (González et al. 2009). Conventional $\mathrm{U}-\mathrm{Pb}$ monazite and zircon, chemical Th-U-Pb total monazite, and $\mathrm{Ar}-\mathrm{Ar}$ hornblende plateau ages from paragneisses, orthogneisses and amphibolites range between 475 and $457 \mathrm{Ma}$ and constrain the timing of regional highgrade metamorphism to the early to mid-Ordovician (González et al. 2004; Steenken et al. 2006). Steenken et al. (2006) reported a $\mathrm{Th} / \mathrm{Pb}$ SHRIMP monazite age of $478 \pm 4 \mathrm{Ma}$ for a migmatite from the northern part of the complex, and a $\mathrm{Pb} / \mathrm{Pb}$ age of $460 \pm 12 \mathrm{Ma}$ for peralumniuos S-type garnet leucomonzogranite from the central part of the complex. Detrital ages of the NMC define a maximum around $530 \mathrm{Ma}$ (Steenken et al. 2006; Drobe et al. 2009).

In the Sierra de Chepes, an early to middle Cambrian metamorphism was proposed by Pankhurst et al. (1998) based on an $\mathrm{Rb}-\mathrm{Sr}$ errorchron of $513 \pm 31 \mathrm{Ma}$. Banded schist from the Sierras de Chepes yielded detrital ages between 540 and $511 \mathrm{Ma}$ with an average of $525 \mathrm{Ma}$ (Drobe et al. 2010 this volume).

Büttner et al. (2005) proposed that for the Sierra de Quilmes metamorphic complex the metamorphic peak in migmatites and calc-silicate rocks is at or slightly prior to $\sim 470 \mathrm{Ma}$.

In Table 1, a summary of the P-T constraints and ages of the Famatinan metamorphism is presented. Therefore, it can be concluded that the Famatinian orogen consists of two stages of compression, one related to the onset of subduction at around $500 \mathrm{Ma}$ and another stage at ca. $470 \mathrm{Ma}$ that is related to the cessation of the Famatinian magmatism.

\section{Magmatism in the Eastern Sierras Pampeanas}

Rapela et al. (1990) separated granitoids of the Sierras Pampenas into G1, G2 and G3 that roughly correspond in time to the Pampean, Famatinian, and Achalian orogenies. Rapela et al. (1998), Quenardelle and Ramos (1999), Pankhurst et al. (2000) and Rapela (2000) considered that the Pampean magmatism is arc-related with minor postcollisional peraluminous intrusions. Famatinian magmatism is arc-related and I-type in the west and grades into S-type granitoids toward the continent. Devonian magmatism would be either arc-related with a Devonian subduction along the western margin of the Precordillera terrain or the result of post-Ordovician uplift.

\section{Ediacaran to Cambrian Granitoids}

Calc-alkaline magmatic rocks of Ediacaran and Cambrian age form the batholith of Sierra Norte and extend discontinuously southward along the Sierra Chica (Rapela et al. 1998). These rocks consist of metaluminous to weakly peraluminous granitoids and associated volcanic rocks (Lira et al. 1997) and exhibit intrusive contacts with the metasedimentary host. Granodiorites and monzogranites are the dominant rocks with late-stage rhyolites, and miarolitic monzogranites (Lira et al. 1997). Aplites, porphyries, and pegmatites intrude all the sequences (Rapela et al. 1991). The geochemistry suggests that these granitoids are arc-related (Lira et al. 1997) and would provide a record of subduction and convergent margin tectonics along the western margin of Gondwana in the late Neoproterozoic. Geochronological studies from the Sierra Norte granitoids (Schwartz et al. 2008) indicate a period of emplacement bracketed between 550 and $-530 \mathrm{Ma}$. A SHRIMP U-Pb zircon age of Ma $515 \pm 4$ was obtained for the Ojo de Agua granite in northeastern Sierra Norte (Stuart-Smith et al. 1999).

Cambrian granitoids (the G1b suite of Rapela et al. 1998) located in the Sierra Grande and Sierra de Comechingones are peraluminous anatectic melts of the metasedimentary country rocks (Rapela et al. 1998). Ages of these groups of plutons are bracketed between $523 \pm 2$ for El Pilón (Rapela et al. 1998, 2001) and $529 \pm 3.4$ for the Juan XXIII pluton (Escayola et al. 2007; Fig. 2).

In the Sierra de San Luis, Cambrian granitoids would correspond to orthogneisses interlayered with the metaclastic units of the Cambrian CMC. In the NMC, an age of ca. $530 \mathrm{Ma}$ (Vujovich and Ostera 2003) was calculated for a granodiorite located in the northern part of the complex. 


\section{Ordovician Granitoids}

Pankhurst et al. (2000) have identified three distinct granite-types: a dominant I-type, small-scale S-type, and tonalite-trondhjemite-granodiorite, which are contemporaneous within the 484-463-Ma interval (Dahlquist et al. 2008 and references therein). I-type magmatism is represented by tonalites, granodiorites, minor monzogranites, and gabbros that can be traced from the NW in Catamarca and La Rioja down to the Sierras de Valle Fértil-La Huerta in the San Juan province and the Sierra de San Luis. The S-type granitoids are developed in Sierra de Velasco, Sierra de Chepes, and in a sector of the Sierra de San Luis (Steenken et al. 2006, 2008). The TTG group (TTG, i.e. El Hongo, Calmayo, La Fronda, Guiraldes, La Playa and Paso del Carmen tonalite to granodiorite plutons) is emplaced in the Sierra Grande except for the Calmayo group (500-480 Ma, U-Pb zircon, Rapela et al. 1998), which intrudes the Sierra Chica Complex.

López de Luchi et al. (2007) considered that the Ordovician granitoids (ca.500-470 Ma) of the Sierra de San Luis (Fig. 4) are synkinematic with compressive deformation related to the early stages of Famatinian convergence. These authors proposed a separation of the granitoids of the Sierra de San Luis into an Ordovician tonalite suite (OTS; metaluminous to mildly peraluminous calcic tonalite-granodiorites) and an Ordovician granodiorite-granite suite (OGGS; peraluminous calcic to calcalkaline granodiorite-monzogranites). In the Conlara Metamorphic Complex, the OGGS (Fig. 4a) comprises the early Ordovician monzogranite to tonalitic plutons (i.e. La Tapera, El Peñón, El Salado) and the group of large

(a)

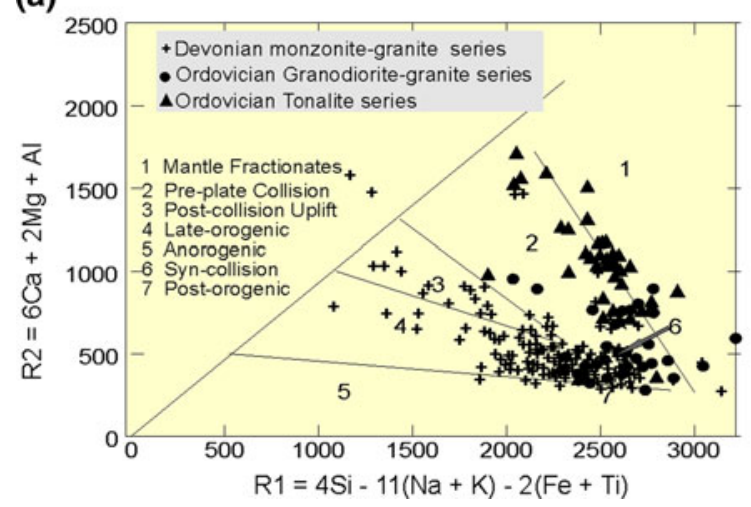

Fig. 4 Diagnostic features of the Ordovician and Devonian granitoids of the Sierra de San Luis. a Tectonic classification R1-R2. More evolved granites cluster in the syncollisional field. Samples of the Ordovician Tonalite Suite are located along the limit between mantle fractionates and pre-plate collision fields, which would suggest mafic sources. Rocks from the Ordovician granodiorite-granite suite trend from the pre-plate collision to syncollisional fields, which correlate with their dominant crustal sources. Devonian hybrid granitoids granitic pegmatites, which show comparable deformation microstructures.

Lower Ordovician metaluminous calc-alkaline granitoids which constitute the principal lithologies of the Sierras de Chepes, Malanzán and Los Llanos (Fig. 2) frequently exhibit mingling relationships with gabbro diorite or quartz diorite. The most important granitoid unit is the $490 \pm 5 \mathrm{Ma}$ (U/Pb zircon age) Chepes Granodiorite (Pankhurst et al. 1998).

Ordovician metagranitoids of the Sierra de Velasco (Toselli et al. 2005, Báez et al. 2005) consist of strongly peraluminous porphyritic two-mica-, garnet-, sillimaniteand kyanite-bearing meta-monzogranites (Rossi et al. 2005). Subordinate varieties include biotite-cordierite meta-monzogranites and biotite meta-granodiorites and meta-tonalites. In the southern part of the Sierra, the main lithologies are metaluminous to weakly peraluminous biotite-hornblende meta-granodiorites and meta-tonalites (Bellos 2005).

In the Sierra de Ancasti, Ordovician granitoid magmatism is represented by calc-alkaline and metaluminous plutons and minor garnet-bearing two-mica granite stocks (Reissinger 1983; Rapela et al. 2005). In the Sierra de Quilmes, Famatinian magmatism is represented by the composite peraluminous to metaluminous granitoids of the Cafayate pluton (Büttner et al. 2005).

\section{Devonian to Lower Carboniferous Granitoids}

Paleozoic magmatism in the Sierras Pampeanas ended with the intrusion of a suite of middle Devonian to Lower Carboniferous batholiths (López de Luchi 1996;

(b)

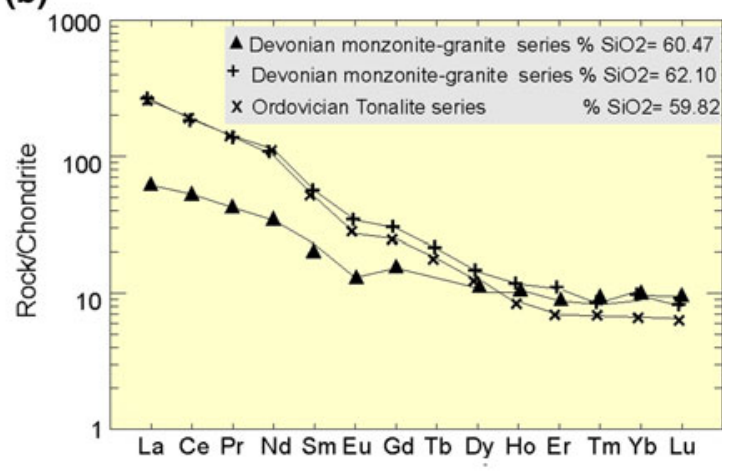

extend from the post-collisional uplift to late-orogenic fields indicating enriched mafic sources to the syn-collisional field, which represent either crustal derived or fractionated melts. b Chondritenormalized REE patterns (Boynton 1984) for rocks with $\mathrm{SiO}_{2}<66 \%$. Note that the Devonian intermediate rocks show higher $(\mathrm{Gd} / \mathrm{Yb})_{\mathrm{N}}$, which would suggest their deeper source and an enrichment in light rare-earth elements 
Stuart-Smith et al. 1999; Pinotti et al. 2002; Siegesmund et al. 2004). They were considered either as post-Famatinian or post-orogenic (Rapela et al. 1998) or as the Achalian granite group. In the Sierra de Córdoba, the Devonian Achala Batholith is a peraluminous, alkali-calcic granitoid with sharp and discordant contacts, which would represent variable proportions of a juvenile mantle component and crustal melts formed by dehydration melting of biotite-bearing gneisses (Rapela et al. 2008). The Cerro Aspero batholith in Sierra de Comechingones is made up of biotite granite and leucogranites (Pinotti et al. 2002, 2006). In the Sierra de San Luis, voluminous Devonian batholiths (Las Chacras-Potrerillos, Renca, La Totora, and El Hornito) are made up of an I-type hybrid monzonite-granite suite with metaluminous alkali-calcic (393-385 Ma) monzonitequartz monzonite-granodiorite \pm monzogranite and peraluminous alkali-calcic monzogranites (Fig. 4a, b) (López de Luchi et al. 2007). Undeformed granites of Lower Carboniferous age (Dahlquist et al. 2008) are located in the north (Báez et al. 2005) and central (Grosse et al. 2008) parts of the Sierra de Velasco. They have some features in common with the Devonian granitoids, i.e. nearly circular shapes, general lack of pervasive solid-state deformation, discordant relationships with the host, shallow emplacement, syeno- to monzogranitic compositions, porphyritic textures and an abundance of pegmatites and aplites. Miller and Söllner (2005) proposed that the Devonian to early Carboniferous magmatism is related to post-orogenic regional crustal heating, whereas Grosse et al. (2008) proposed that the general age decrease of the Achalian magmatism from south to north could have been related to a progressive delamination of the crust coupled with upper mantle upwelling from south to north.

Neoproterozoic (ultra-) mafic rocks of the Sierra de Córdoba

The NNW-SSE trending eastern belt is composed of lherzolite with interlayered websterite and subordinate harzburgite, abundant pyroxenite and gabbros. Mutti (1992) described abundant leucocratic plagiogranite dikes. Escayola et al. (1996) assigned the tectonic setting to an ensialic back-arc basin, whereas Ramos et al. (2000) interpreted the belt as ophiolite remnants of a back-arc zone. Anzil and Martino (2009) considered that the ultramafic sequence would correspond to an obducted lens or slice of oceanic mantle, probably part of a basal tectonite of an ophiolitic complex.

The ultramafic-mafic units of the western belt, which extend along $\sim 300 \mathrm{~km}$, are made up of harzburgites that were metasomatized by intrusive basaltic dikes (Escayola et al. 2007). Basaltic dikes are made up of plagioclasehornblende \pm orthopyroxene \pm clinopyroxene. Spinel dunites are close to these dikes. Escayola et al. (1996) interpreted the western belt as a suture zone and considered the ultramafic rocks as dismembered ophiolites with MORB affinities. Escayola et al. (2007) suggested a suprasubduction-zone ophiolitic complex formed at a backarc stage. Sm-Nd dating of basalt and gabbro dikes, pyroxenites, and impregnated peridotites of the western belt yielded an isochron age of $647 \pm 77 \mathrm{Ma}$. The $\varepsilon \mathrm{Nd}_{(647)}$ value of +5.2 is consistent with an oceanic or back-arc origin for the ophiolite sequence (Escayola et al. 2007).

Gabbros with OIB signatures located in the Sierra de Comechingones, which result from the subduction of a mid-ocean ridge beneath the paleo-Pacific Gondwana margin, are related to the high-grade metamorphism of the Sierras de Córdoba (Tibaldi et al. 2008).

Within the CMC, ultramafic rocks have not been reported yet. However, scarce amphibolites are distributed in a N-S belt through Sierra del Morro, San Felipe and Villa de Praga. Some tungsten deposits are genetically related to them (de Brodtkorb et al. 2005).

Ordovician mafic rocks in the Sierra de San Luis and Sierra de Chepes

Mafic to ultramafic Ordovician complexes are developed in the central part of the Sierra de San Luis, whereas gabbros are recognized as small plutons associated with the calcalkaline granitoids of the Sierra de Chepes, Sierra de Fiambalá and in the Famatina Complex in the Sierra de Famatina (Fig. 1). In the Pringles Metamorphic Complex, 506-480 Ma mafic to ultramafic bodies for which back-arc or marginal basin settings were proposed (Sims et al. 1998; Hauzenberger et al. 2001; Steenken et al. 2008) are represented by norites to gabbro-norites with minor ultramafic rocks. On both sides of the mafic to ultramafic bodies, a metamorphic gradient from granulite to greenschist facies is observed (Delpino et al. 2007), and therefore a contact metamorphic origin for the granulite-facies paragenesis was suggested (Hauzenberger et al. 2001; Steenken et al. 2005, 2006). Amphibole-bearing gabbros associated with the calc-alkaline complexes of the Sierra de Chepes, i.e. the Tama gabbro exhibit mingling relationships with the host granodiorite (Pankhurst et al. 1998).

\section{Isotopic constraints for the Neoproterozoic-early Paleozoic geodynamic evolution of the Gondwana margin}

Sm-Nd parameters were calculated at $540 \mathrm{Ma}$ for all the metamorphic rocks, whereas the igneous rock data were calculated at the crystallization age (Table 2, Figs. 5, 6; see also Drobe et al. 2009). 


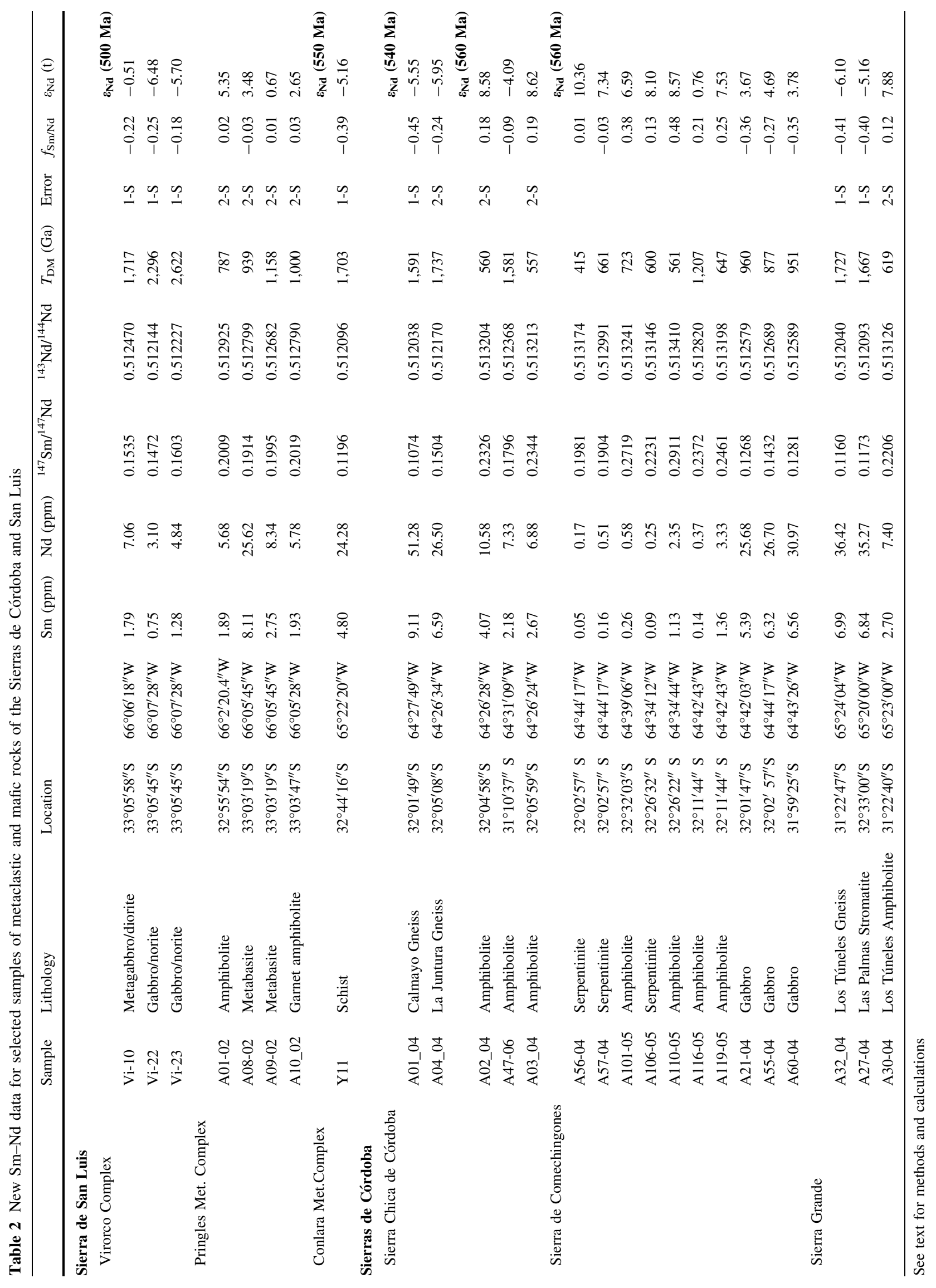




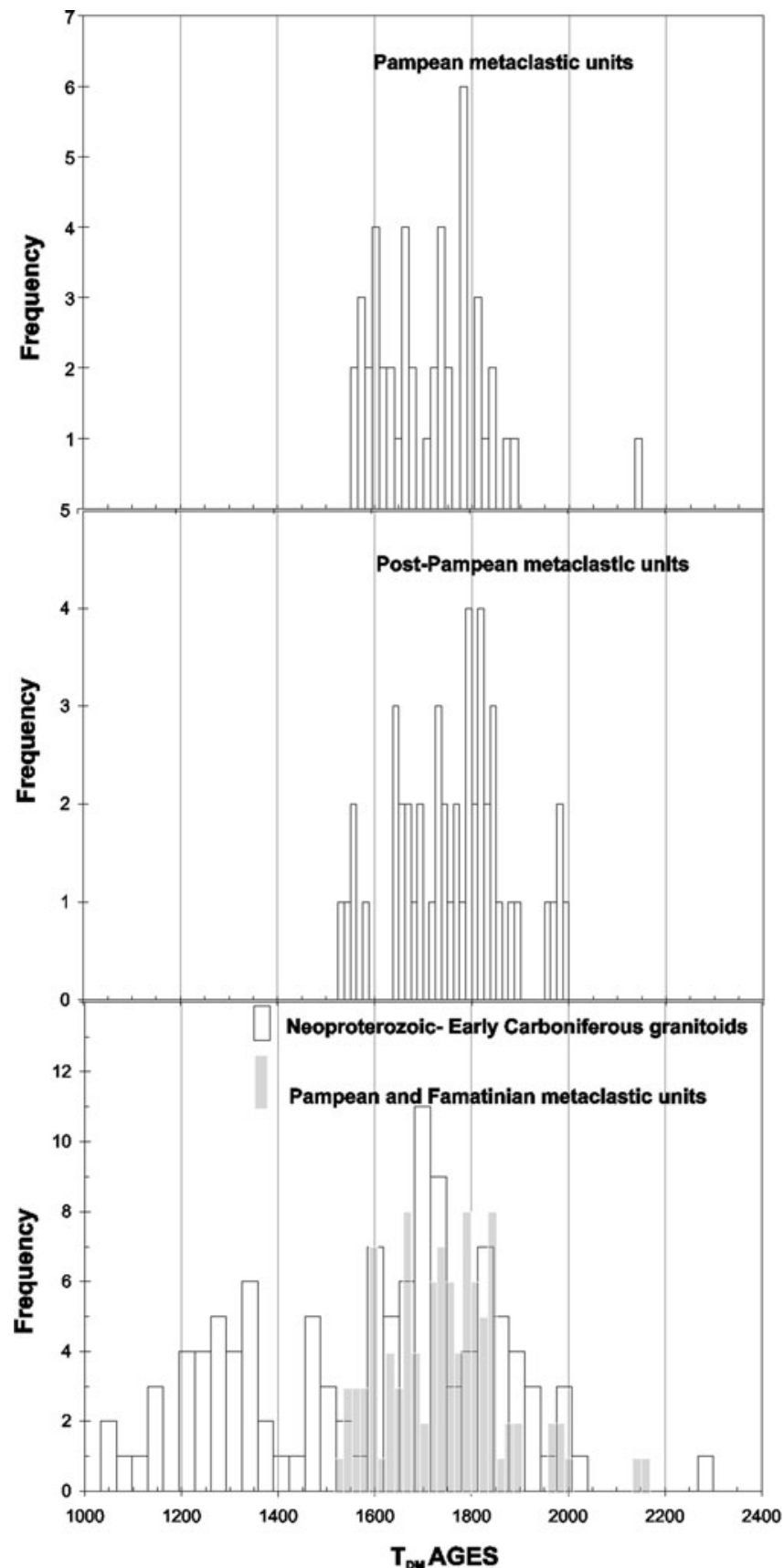

Fig. 5 Frequency distribution plots of $T_{\mathrm{DM}}$ ages for metaclastic and igneous felsic rocks of the Eastern Sierras Pampeanas. Comparison between the data collection indicates that the main period of juvenile input to the continental crust or alternatively reworking of a younger unexposed segment of the crust corresponds to the Devonian-Early Carboniferous. Ordovician felsic rocks with model ages younger than

Sm-Nd fingerprints for the metamorphic rocks

Metamorphic rocks of the Sierras Pampeanas were plotted in the $f_{\mathrm{Sm} / \mathrm{Nd}} \mathrm{vs} \varepsilon \mathrm{Nd}_{(540)}$ diagram (Fig. 6b). As the majority of the rocks exhibit $f_{\mathrm{Sm} / \mathrm{Nd}}$ in the interval of sedimentary derived crustal rocks, i.e. between -0.3 and $-0.45, T_{\mathrm{DM} 1}$

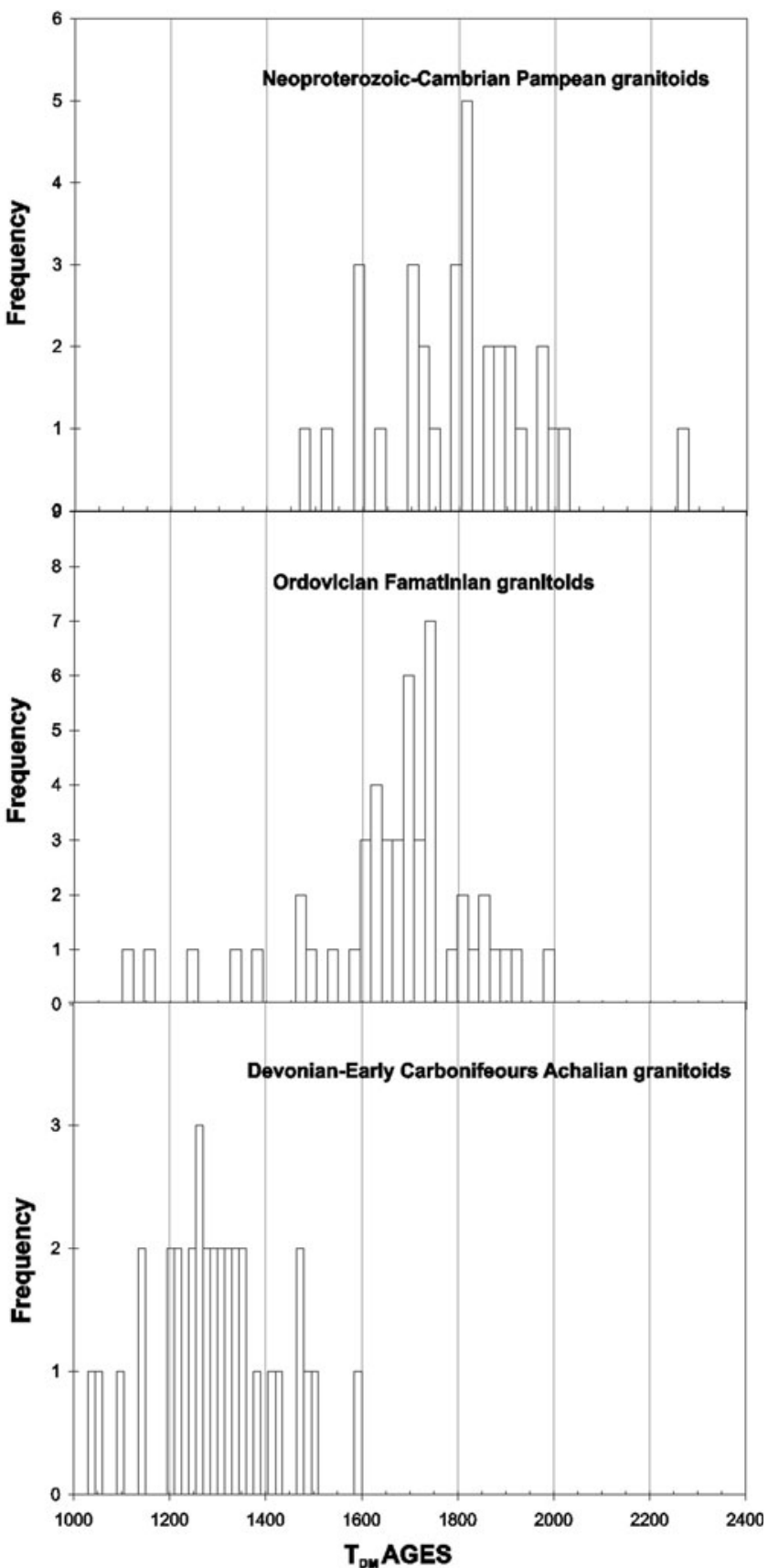

$1.4 \mathrm{Ga}$ correspond to a part of the TTG suite of the Sierras de Córdoba. Data base taken from Rapela et al. (1998), Pankhurst et al. (1998), Millone et al. (2003), Pinotti et al. (2002), Steenken et al. (2004, 2006), Otamendi et al. (2006), Grosse et al. (2008), Collo et al. (2009), Drobe et al. (2009, 2010 this volume) and this work

ages (Drobe et al. 2009) are inferred to reflect the weighted average crustal residence time of all the detrital contributions from the source area. $\mathrm{Sm}-\mathrm{Nd}$ results for the metamorphic basement suggest that the $T_{\mathrm{DM} 1}$ age interval of $1.8-1.7 \mathrm{Ga}$, which is associated with the less radiogenic ${ }_{\varepsilon} \mathrm{Nd}_{(540)}$ values of -6 to -8 , can be considered as the mean 


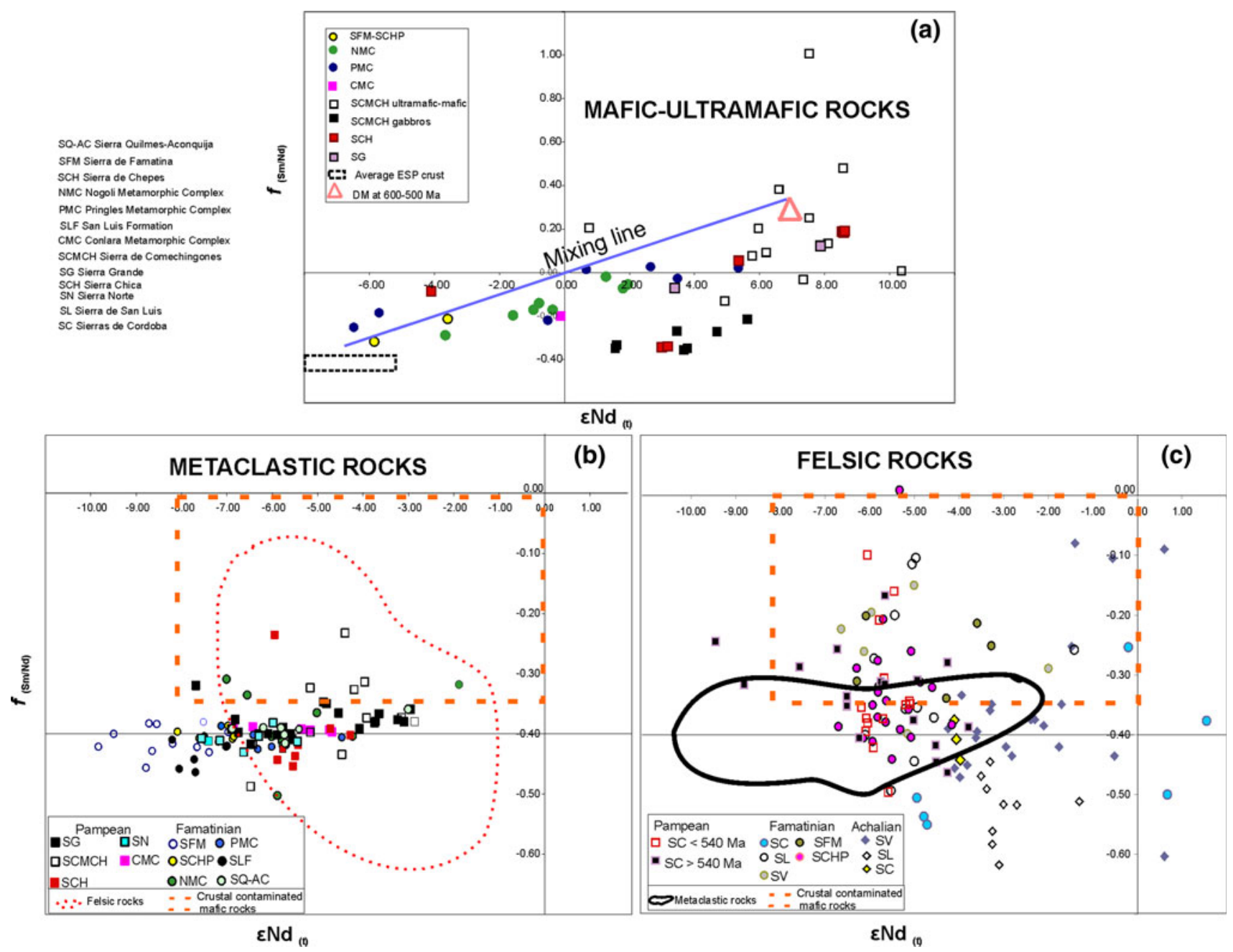

Fig. $6 \varepsilon_{\mathrm{Nd}_{(\mathrm{t})}}$ vs. $f_{\mathrm{Sm} / \mathrm{Nd}}$ data showing the Eastern Sierras Pampeanas metaclastic and igneous rocks. a Mafic-ultramafic rocks. Depleted mantle $(D M)$ sources plot in both right quadrants depending upon the nature and degree of light-rare-element enrichment of the source at the time of extraction of the melts. Values of $\varepsilon \mathrm{Nd}$ and $\mathrm{f}_{\mathrm{Sm} / \mathrm{Nd}}$ for $\mathrm{DM}$ at 500-600 Ma and as a field (dashed line) for the crustal reservoir represented by the oldest recorded continental crust of the Eastern Sierras Pampeanas i.e. $T_{\mathrm{DM}}$ ages between 1.8 and $1.7 \mathrm{Ga}$ are shown. Any mixture between these two reservoirs should lie along a mixing line. Ordovician mafic-ultramafic complex and gabbros are located close to the crustal field suggesting crustal component incorporation. b Metaclastic rocks. Note that most of the metaclastic rocks are

average crustal composition for the Eastern Sierras Pampeanas (Figs. 5, 6b). Younger $T_{\mathrm{DM} 1}$ ages and more radiogenic $\varepsilon \mathrm{Nd}$ values in metaclastic rocks could reflect stages of additional juvenile material, a different crustal source or a petrogenetic process. Collo et al. (2009) indicated that the Gondwanan isotopic signature for the Mesoproterozoic source of the Sierra de Famatina $\left(T_{\mathrm{DM}}\right.$ ages 1.8 and $1.6 \mathrm{Ga}$ ) differs from the $1.1-0.8 \mathrm{Ga}$ 'Laurentianlike' Grenville signature.

Detrital zircon age patterns for the Pampean metaclastic rocks of the Sierras de Córdoba, the Conlara Metamorphic restricted to crustal values of $\mathrm{f}_{\mathrm{Sm} / \mathrm{Nd}}$ and that the $\varepsilon \mathrm{Nd}_{(\mathrm{t})}$ is less radiogenic for the Ordovician metaclastic rocks, which suggest more recycling. c Felsic igneous rocks. Pampean rocks older than $540 \mathrm{Ma}$ separate into two groups. The group with $\varepsilon \mathrm{Nd}_{(\mathrm{t})}$ values $>-5$ corresponds to the rocks of the Sierra Chica de Córdoba in which mafic microgranular enclaves are found (and show $T_{\mathrm{DM}}<1.6 \mathrm{Ga}$ ). Rocks with $\varepsilon \mathrm{Nd}_{(\mathrm{t})}$ values $<-5$ correspond to granitoids for which the metaclastic host is less radiogenic (both sharing $T_{\mathrm{DM}}$ ages ca.1.7-1.8 Ga). A trend from more radiogenic $\varepsilon \mathrm{Nd}_{(\mathrm{t})}$ values with time is observed, and it is accompanied by values of $f_{\mathrm{Sm} / \mathrm{Nd}}$ more negative than the average continental crust. See text for comments

Complex and the Ancasti Formation exhibit prominent Mesoproterozoic and Brasiliano peaks (Fig. 2), whereas those for the Ordovician metamorphic rocks independently of their metamorphic grade show some Pampean and a less pronounced Grenvillian peak suggesting a limited Grenvillian input. As the Sm-Nd model ages (Fig. 2) are older than these peaks, the magmatic-metamorphic events sampled by the zircon cores/rims mainly represent recycled crustal sources.

Although a change in the source for the protoliths of the Ordovician and Pampean metaclastic rocks is reflected 
by the detrital zircon age patterns, the average interval of crustal residence ages is similar. Metamorphic rocks of the same grade from different parts of Eastern Sierras Pampeanas show similar $T_{\mathrm{DM} 1}$ ages (Fig. 2) and crustal $f_{\mathrm{Sm} / \mathrm{Nd}}$ values but less radiogenic $\varepsilon \mathrm{Nd}_{(540)}$ values with decreasing age, which implies an additional recycling process of the same sources during the Ordovician. Low- to medium-grade metaclastic rocks of the Sierras Pampeanas show similar average crustal residence age but more negative $\varepsilon \mathrm{Nd}_{(\mathrm{t})}$ values (Fig. $6 \mathrm{~b}$ ) for the Ordovician units. The Ordovician Pringles Metamorphic Complex and the Cambrian Sierra Chica metamorphic rocks show similar $T_{\mathrm{DM}}$ ages but less radiogenic $(-6) \varepsilon \mathrm{Nd}_{(540)}$ values for the PMC. Pampean high-grade metaclastic rocks of the Sierra Grande de Córdoba and Sierra de Comechingones (Fig. 5) show consistently younger $T_{\mathrm{DM}}$ ages of 1.6-1.5 Ga, $\varepsilon \mathrm{Nd}_{(540)}$ values between -4 and -3 and an $f_{\mathrm{Sm} / \mathrm{Nd}}$ value above the average -0.4 for the continental crust. The Ordovician high-grade rocks of the Pringles Metamorphic Complex exhibits $T_{\mathrm{DM} 1}$ ages between 1.7 and $1.6 \mathrm{Ga}$ (Fig. 5) and a mean $\varepsilon \mathrm{Nd}_{(540)}$ value of -5.5 (Fig. 6b). Since the zircon age pattern suggests a less important Grenvillian contribution to the protoliths of the Pringles Metamorphic Complex, it could be inferred that the Grenvillian component introduced more radiogenic compositions.

Younger average crustal residence ages in the Pampean metaclastic rocks, which can be roughly subdivided into low to medium- and high-grade rocks, can be ascribed to the petrogenetic process. Rocks that underwent partial melting exhibit younger $T_{\mathrm{DM} 1}$ ages than those rocks that lack this process. Although SHRIMP zircon data for the granulite of the Sierra de Comechingones are scarce, the persistence of the Mesoproterozoic peaks (Fig. 2) in the Pampean units (Siegesmund et al. 2010) suggests that younging of the $T_{\mathrm{DM} 1}$ ages results from a petrogenetic process. Otamendi et al. (2006) proposed that the granulites were formed by a short-lived event of local thermal input, which enhanced the possibility that melting was rapid enough to trigger isotopic disequilibrium. Therefore, the $\mathrm{Sm}-\mathrm{Nd}$ data for the high-grade Pampean metaclastic rocks of Córdoba do not identify different sources located east or west of the Sierra de Córdoba as previously proposed by Escayola et al. (2007).

To summarize, increasing metamorphic grade in rocks with similar sources and ages like in the Sierras de Córdoba is associated with a younging of the $T_{\mathrm{DM}}$ ages and more positive $\varepsilon \mathrm{Nd}_{(540)}$ values. In metaclastic rocks of different metamorphic ages, the Grenville source introduces a relatively more positive epsilon. The change of source between the Pampean and the Famatinian metaclastic rocks is related to a higher degree of recycling as evidenced by the less radiogenic epsilon.
Sm-Nd fingerprints for the magmatic rocks

Sources and evolution of neodymium isotopic ratios of the magmatic rocks are analyzed in the $\varepsilon \mathrm{Nd}$ versus $f_{\mathrm{Sm} / \mathrm{Nd}}$ plot (Fig. 6a, c) for time corrected epsilon values (Shirey and Hanson 1986).

\section{Mafic-ultramafic complexes}

Our own database for the mafic rocks (Table 2) was combined with data from Pankhurst et al. (1998), Rapela et al. (1998), Sato et al. (2001), de Brodtkorb et al. (2005) and Escayola et al. (2007). Sm-Nd results for the maficultramafic rocks are heterogeneous, which is evident from the wide range in $\mathrm{Sm}-\mathrm{Nd}$ isotopic compositions (Table 2), with $\varepsilon \mathrm{Nd}_{(540)}$ values ranging from -6.37 to +7 and ${ }^{147} \mathrm{Sm} /{ }^{144} \mathrm{Nd}$ ratios ranging from 0.09 to 0.3 . Consequently, an ample range of $T_{\mathrm{DM}}$ ages were calculated (Table 2).

Rocks of the Eastern belt located in the Sierra Chica de Córdoba (Fig. 6a) can be separated in two groups: maficultramafic rocks with a depleted mantle signature with $\varepsilon \mathrm{Nd}_{\text {(today) }}$ values around $11, \varepsilon \mathrm{Nd}_{(540)}$ values of $6-8.5$ and positive $f_{\mathrm{Sm} / \mathrm{Nd}}$ and another more variable group located in the northern sector in which amphibolites are characterized by negative $\varepsilon \mathrm{Nd}_{(\text {today) }}$ values, positive $\varepsilon \mathrm{Nd}_{(540)}$ values, and negative $f_{\mathrm{Sm} / \mathrm{Nd}}$. $T_{\mathrm{DM} 2}$ ages vary between 570 and $560 \mathrm{Ma}$.

In the western belt in the Sierra de Comechingones, two groups can be recognized (Fig. 6a). One group includes serpentinites and metabasaltic dykes in which $\varepsilon \mathrm{Nd}_{\text {(today) }}$ values can be higher or lower than the depleted mantle. The other group is made up of the gabbros related to the granulite-facies metamporphism, like Intihuasi, Suya Taco and Sol de Mayo in which the $\varepsilon \mathrm{Nd}_{\text {(today) }}$ values are significantly lower than that of the contemporary depleted mantle. If the serpentinites and peridotites are discarded due to the complex processes involved in their genesis, the remaining primitive rocks yielded a $T_{\mathrm{DM} 2}$ age range of 700-600 Ma, which agrees with the WR Sm-Nd isochron age calculated for the ophiolite complex of the western belt (Escayola et al. 2007). It is remarkable that two samples from the area of Los Túneles in the western sector of the Sierra Grande also yielded $T_{\mathrm{DM} 2}$ ages of around $620 \mathrm{Ma}$.

Uncertainties concerning the crystallization age only allows for speculation that rocks of the Sierra de Comechingones mafic complexes with $\varepsilon \mathrm{Nd}_{(540)}$ values higher than the contemporaneous depleted mantle value, could indicate that the original liquid was very primitive and derived from a LREE-depleted source. Alternatively, the original peridotite protolith could have lost LREE elements during selective metasomatism.

Older $T_{\mathrm{DM}}$ ages and lower $\varepsilon \mathrm{Nd}_{(540)}$ values suggest that the $T_{\mathrm{DM}}$ values of these samples reflect enriched signatures and/or a longer crustal residence time (Arndt and Goldstein 
1987). In the northern part of the Sierra Chica (de Brodtkorb et al. 2005, Rapela et al. 1998 and Table 2), rocks considered as amphibolites as well as the gabbros of the Sierra de Comechingones (Fig. 6a) have $\varepsilon \mathrm{Nd}_{(540)}$ values significantly below that of the contemporary depleted mantle and were probably derived from the sub-continental lithospheric mantle. Tibaldi et al. (2008) proposed that the metasomatic enrichment required for OIB-like magmatism was caused by low-degree partial melting of progressively younger and warmer subducted oceanic lithosphere at the Pampean convergent margin and that subsequent melting of the overlying enriched mantle wedge produced OIB magmas.

The norites of the PMC, which plot in the lower left quadrant of Fig. 6a, could be explained by the mixing of mantle and crustal components. Their data plot on a mixing line (Fig. 6a) connecting the DM signature at 500-600 Ma with the average values for the metaclastic rocks of the Pringles Metamorphic Complex. Available data on the amphibolites and komatiitic basalts of the Nogolí Metamorphic Complex, which show negative $\varepsilon \mathrm{Nd}$ and $f_{\mathrm{Sm} / \mathrm{Nd}}$ values, and consequently variable $T_{\mathrm{DM}}$ ages, could also result from a process of mixing with a crustal component. Since the crystallization age of these rocks was calculated from a WR Sm-Nd isochron (Sato et al. 2001), it could represent a mixing line between crustal and depleted mantle components.

The less evolved Devonian magmatic rock of the Las Chacras batholith indicates a younger $T_{\mathrm{DM}}$ age (Fig. 5) coupled with an increase in the $\varepsilon \mathrm{Nd}$ value (Fig. 6c).

The Sierras de Córdoba mafic-ultramafic complexes occupy both right quadrants in Fig. 6a, whereas a group of the Ordovician mafic rocks of the Sierras de San Luis are located in probable mixing trends of depleted mantle and continental crust. The magmatic units, which yielded positive $\varepsilon \mathrm{Nd}_{(540)}$ values, indicate juvenile character. Some samples (Fig. 6a) show high initial $\varepsilon \mathrm{Nd}_{(540)}$ values close to the model depleted mantle curve (Wu et al. 2003). However, the range of the initial $\varepsilon \mathrm{Nd}_{(540)}$ values and the spread of $T_{\mathrm{DM}}$ ages suggest either that the original magma was not a pure primary melt or that the $\mathrm{Sm}-\mathrm{Nd}$ system has been modified by metamorphism or metasomatism. The $T_{\mathrm{DM}}$ ages of rocks with a depleted mantle signature (which follows the path of the model depleted mantle) may suggest that formation of oceanic crust in the Sierra Chica could have been active up to $560 \mathrm{Ma}$; whereas in the Sierra de Comechingones, formation of oceanic crust was active from around 600-700 Ma.

In summary, the analysis of the Sm-Nd results indicates two types of Pampean-related mafic rocks in which no interaction with the continental crust in the sense of mixing or assimilation process is recognized. One group shows a DM signature and LREE-depleted sources, which could indicate a stage of ocean crust formation, and another younger group with a signature of enrichment (cf. Siegesmund et al. 2010). On the other hand, in the Ordovician rocks, the processes of mixing/assimilation of DM signature melts and continental crust are characteristic. Therefore, the geodynamic scenario for the Ordovician mafic rocks could imply thicker continental crust than for the emplacement of the Pampean mafic rocks or alternatively, a fast extensional process (extensional collapse) could prevent modification of the mafic melts in their ascent to the emplacement level.

\section{Felsic rocks}

The overall high abundance of felsic intrusive rocks and the paucity of intermediate compositions suggest that crystal fractionation of mafic parental magmas was not important. The partial melting of crustal sources during basalt underplating or during crustal delamination is the dominant process at least during the Pampean and Ordovician cycles. Pre-540 Ma (Figs. 5, 6c) granitoids of the Sierra de Córdoba make up two clusters: one that would be entirely crustal, since they have $T_{\mathrm{DM}}$ ages older than $1.75 \mathrm{Ga}$ and $\varepsilon \mathrm{Nd}_{(540)}$ values lower than -5 , and another cluster which corresponds to samples from Sierra Chica de Córdoba in which $\varepsilon \mathrm{Nd}_{(540)}$ values are more radiogenic and $T_{\mathrm{DM}}$ ages younger. In the first cluster, melting of a large amount of old sedimentary protoliths can be suggested; whereas in the second, since the host is less radiogenic and older, melting of a variably rejuvenated crust could be assumed. In this area, tonalites and granodiorites carry dioritic enclaves suggesting a mixture of a mafic precursor with metasedimentary sources.

In spite of the episode of mafic magma input to the crust as shown by the ca. $540 \mathrm{Ma}$ gabbros of the Sierra de Comechingones, no evidence of this juvenile input is seen in the post 540 Ma Pampean felsic rocks, which would represent partial melts derived from the older than $1.75 \mathrm{Ga}$ basement (Fig. 6c). Therefore, it could be proposed that mafic magma should have just controlled the melting process through delamination or underplating.

Although juvenile input is suggested by the mafic rocks in the Pringles Metamorphic Complex or the gabbros of the Sierra de Chepes, widespread Famatinian magmatism with the exception of the minor TTG suites reworked the old lithospheric sources (Pankhurst et al. 1998). Mostly evolved granitoids dominate the rock spectrum in the Famatinian subduction stage. This fact suggests melting of mostly crustal sources as would be expected in regions of thick continental crust.

Sources for TTG suites of the Sierra de Córdoba are younger. Data from the Guiraldes and La Fronda throndhjemite together with a leucogranite from the northern 
sector of Sierra Chica de Córdoba cluster at a $T_{\mathrm{DM}}$ age of ca.1.3 Ga (see Fig. 5), which is accompanied by an $\varepsilon \mathrm{Nd}_{(540)}$ value of -5 and a $f_{\mathrm{Sm} / \mathrm{Nd}}$ value of -0.55 (Fig. 6c). One throndhjemite of the San Carlos Massif and the La Playa granodiorite show the youngest $T_{\mathrm{DM}}$ age and a positive or slightly negative value of $\varepsilon \mathrm{Nd}_{(470)}$, which suggests a juvenile input.

López de Luchi et al. (2007) proposed crustal sources for the Ordovician tonalite series of the Sierra de San Luis based on the low $\mathrm{Cr}$ and $\mathrm{Ni}$ and relatively high $\mathrm{K},{ }^{87} \mathrm{Sr} /{ }^{86} \mathrm{Sr}$ ratios $(0.70850-0.71114)$, and an $\varepsilon \mathrm{Nd}_{(470)}$ value $(-5.3$ to $-6.0)$, which precludes an origin from variably fractionated mantle melts. The REE pattern of the OTS (Fig. 4b) reveals subordinate negative Eu anomalies indicating little plagioclase control during magma evolution, which combined with the low total REE may suggest a source that underwent previous melting and possibly consumption of plagioclase.

Field evidence and the age of the mafic-ultramafic rocks (506-480 Ma) suggest that they crystallized almost at the same time or slightly before the tonalite-granodiorite OTS (481-468 Ma) and the $496 \mathrm{Ma}$ of the Paso del Rey S-type granitoids of the OGGS (López de Luchi et al. 2007). Because mafic melts are denser than hydrous granitoid melts, large volumes could have intruded into the middle to lower crust (as indicated by the gravimetric results and thermal modeling by Kostadinoff et al. 1998; Steenken et al. 2005). A differentiation/assimilation process in the lower crust could account for the mixed crustal-mantle signature of the Ordovician mafic rock as is evident in the norites of the Virorco complex (Fig. 6a). Mafic magmatism could thus result from the breaking off of a slab of oceanic crust during ongoing convergence or from the melting of the lower crust heated from below by underplating of basalts or input of heat from delamination of the lower crust.

The combination of the time span of the mafic emplacement from 506 to $480 \mathrm{Ma}$ with that of the felsic igneous rocks from 495 to $470 \mathrm{Ma}$ (Steenken et al. 2006) argues for a $25 \mathrm{Ma}$ interval of magmatic activity in the Sierra de San Luis, which is coincident with the time span assigned to the Famatinian magmatism (Dahlquist et al. 2008 and references therein). Therefore, in the PMC granulite-facies metamorphism, mafic magma emplacement and I-type and minor S-type magmatism are related to the active subduction stage of the Famatinan orogeny, a situation similar to the rest of the Ordovician magmatism along the margin of Gondwana.

Devonian to early Carboniferous magmatism could have tapped a juvenile source, which mixed with a crustal endmember in order to generate the intermediate to acidic rocks as already proposed by López de Luchi et al. (2007). The Pampean Paleoproterozoic crust or an unexposed lower crustal segment could represent the aforementioned crustal end-member. Alternatively, the granitoids may represent successive episodes of fractionation of enriched mantle-derived melts. There is almost no overlap between the $\mathrm{Sm}-\mathrm{Nd}$ results of this younger group of granitoids (Figs. 5, 6c) and the rest of the felsic rocks of the Sierras Pampeanas.

Although some discussion could be addressed concerning the degree of crust-mantle interaction in pre-Devonian times, crustal reworking is dominant, whereas processes during the Achalian orogeny led to different geochemical and isotopic signatures (López de Luchi et al. 2007). The high heat flow associated with the rising mafic magma during extension is inferred to have partially melted the crust during peak metamorphism in the Pampean orogeny; whereas in the Ordovician, the continental arc setting favored extensive interaction between mantle derived and crustal melts. In contrast, during Devonian times extensive melting of an enriched mantle led to a huge volume of felsic magmatism and/or alternatively a different crustal segment is involved as source of the felsic melts.

\section{Models for the early Paleozoic tectonic evolution of the Eastern Sierras Pampeanas}

\section{Models for the Pampean Orogeny}

Two conflicting models have been proposed to explain the (580-510 Ma) Pampean orogeny. One model follows the concepts initially published by Ramos et al. (1986) involving a terrane collisional model in which a terrane (Pampia or Western Sierras Pampeanas according to different interpretations by Rapela et al. (1998, 2007) is accreted to the western margin of Gondwana. The second situation evokes a non-collisional model, which considers that the main phase of the orogen is driven by the subduction of a seismic ridge (Schwartz et al. 2008 and references therein).

The first model evokes a collisional origin, mostly between the Río de la Plata craton (RPC) and the Pampia Terrane as proposed by Ramos et al. (1986) and Ramos (1988) in which the orogen was initially related to a magmatic arc established on the Pampia Terrane prior to the collision. Kraemer et al. (1995) revised this model and proposed a long-lasting orogen between ca. 900 and $540 \mathrm{Ma}$. This orogen would have started with an initial passive margin stage between the Pampia Terrane and the Río de la Plata Craton (RPC), which was followed by the onset of an eastward subduction beneath the RPC and a retro-arc extension, responsible for the ophiolitic belts invoked by these authors. The end of this process was outlined with the collision of these landmasses and the 
setting for the Puncoviscana Basin, which would have worked as a peripheral foreland basin. Rapela et al. (1998) considered that the Pampean Orogeny was a short-lived orogenic cycle (ca.10 Ma) triggered by an east-dipping subduction beneath the RPC that would have formed a magmatic arc in the Sierras de Córdoba ca. $535 \mathrm{Ma}$; followed by the collision with the Pampean Terrane causing high-grade metamorphism and peraluminous granitoid emplacement at 530-520 Ma.

More recently, different interpretations as the ones proposed by Escayola et al. (2007) or Collo et al. (2009) reframed the collisional models influenced by $\mathrm{Sm}-\mathrm{Nd}$ isotopic data and zircon provenance patterns. Escayola et al. (2007) proposed an initial stage in which a west dipping subduction could have started ca. 650 Ma between the RPC and a Grenvillian (?) Pampia terrane with the development of a 0.6 Ma magmatic arc and a back-arc basin at the western side of this arc. After the RPC collided with the magmatic arc, widening of the back-arc basin continued, and the onset of an east-dipping subduction process underneath the arc took place. This basin would have been closed ca. $560 \mathrm{Ma}$ followed by a collisional stage between this landmass and the Pampia terrane. According to their interpretation, this collision (between 580 and $540 \mathrm{Ma}$ ) would have caused ophiolite obduction and crustal thickening, a tectonic setting with promoted decompression, high-grade metamorphism and crustal melting between 540 and $515 \mathrm{Ma}$. On the other hand, Collo et al. (2009) had taken into account the existence of three blocks in the Eastern Sierras Pampeanas: a Brasiliano arc, Córdoba Terrane and the Pampia Terrane. In this case, the orogeny would have been caused by subsequent collisions and the ultimate closure of the Puncoviscana ocean $\sim 530 \mathrm{Ma}$.

The other hypotheses consider that the Pampean orogeny could have been formed as a non-collisional orogen. According to Schwartz et al. (2008), the orogenic evolution started with a long-lived early subduction between 555 and $525 \mathrm{Ma}$ that would have built a calc-alkaline magmatic arc, which could partially provide the sediments to build a long accretionary prism. This scenario could have been subject either to: (1) a subduction rollback episode, (2) a partial density-driven subduction-thickened lower lithosphere or (3) a subduction of a mid-ocean spreading center to produce the short-lived pulse of high-grade metamorphism and peraluminous/mafic magmatism in the accretionary prism. However, these authors conclude that the most plausible option would be the one that involves the subduction of a seismic ridge beneath the accretionary prism developed in the RPC, excluding a continental collision (Schwartz and Gromet 2004) and the existence of the Pampia craton. As noted previously by Escayola et al. (2007), all these models have two statements in common: (1) the subduction of oceanic lithosphere was east dipping beneath the RPC, and
(2) the supracrustal sequences of the Eastern Pampean Ranges represent the passive/active margin deposits along the continental platform of that craton.

On the basis of a geochronological study in the RPC, Rapela et al. (2007) proposed that these supracrustal sequences or protoliths of the metasedimentary rocks of the ESP could have been initially deposited as large submarine fans at the southern tip of the RPC and the Kalahari craton and fed by a magmatic arc located at the present African side. They conclude that the closing of the Clymene Ocean (Trindade et al. 2006), which might have separated the RPC from the Grenvillian terranes such as Amazonia, Arequipa-Antofalla and Western Sierras Pampeanas, would have led to a right-lateral accretion of a Western Sierras Pampeanas Terrane (namely Cuyania without the Precordillera Terrane in the sense of Ramos (2008)) to create the Pampean belt at 540-520 Ma. After the collision, a continued right-lateral movement would have displaced the Pampean mobile belt to its present position alongside the Río de la Plata Craton through the dextral Trans-Brasiliano shear zone. Following these ideas, Drobe et al. (2009) proposed that the PMC and NMC, in the Sierras de San Luis, might have been deposited since $515 \mathrm{Ma}$, as an infill of the post-Pampean back-arc basins. Recently, new precise geochronological data allowed Siegesmund et al. (2010) to invoke a two-stage model determining the onset of metamorphism at 550-540 Ma and the docking of a Mesoproterozoic terrane ca. $530 \mathrm{Ma}$.

\section{Models for the Famatinian Orogeny}

The evolution and geodynamic setting of the Sierras Pampeanas during the Ordovician was essentially considered a collisional orogeny (Fig. 7). The (500-440 Ma) Famatinian orogen consists of a continuous upper-plate continental arc, associated with some contribution from juvenile mantle material and ensialic basins (Collo et al. 2009; Dahlquist et al. 2008), which stretched between southern Peru and northern Patagonia (Casquet et al. 2006; Chew et al. 2007; Martínez Dopico et al. 2010). The first collisional model (Ramos 1988) invokes the collision of the Laurentia-derived Precordillera/Cuyania Terrane, which docked with the proto-Andean margin of Gondwana in the mid to late Ordovician (Thomas and Astini 2003 and references therein). More recently, Dahlquist et al. (2008) proposed a model for the development of a relatively shortlived (481-463 Ma) Famatina Complex (Famatina magmatic arc and related ensialic basins) along the border of the Pampean basement, related with an ongoing subduction along the margin of their Western Sierras Pampeanas Terrane. Although magmatism and closure of the ensialic basin were related to a compressive event, no indication of the geodynamic setting of the compression was addressed. 
(a) $640.580 \mathrm{Ma}$

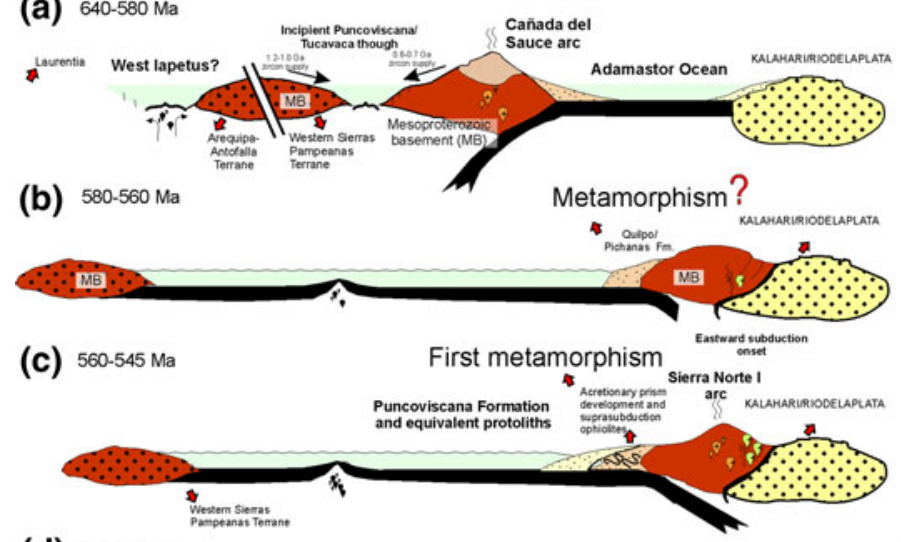

(d) $545.535 \mathrm{Ma}$



(f) $535-515 \mathrm{Ma}$

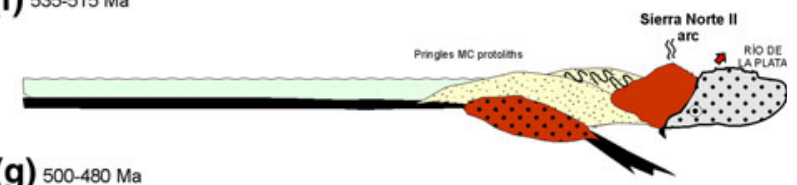

(g) $500-480 \mathrm{Ma}$

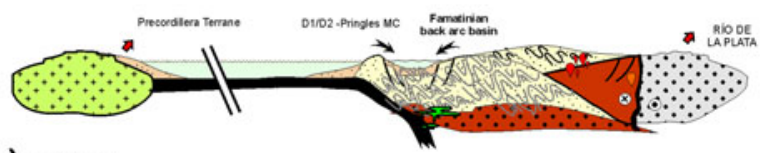

(h) ca. 465 Ma.

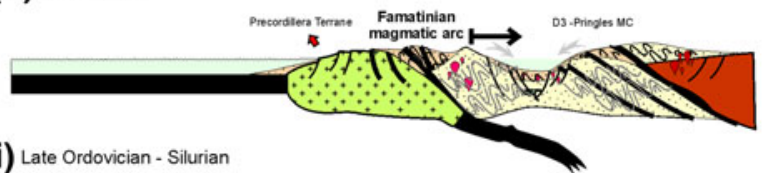

(i) Late Ordovician - Silurian

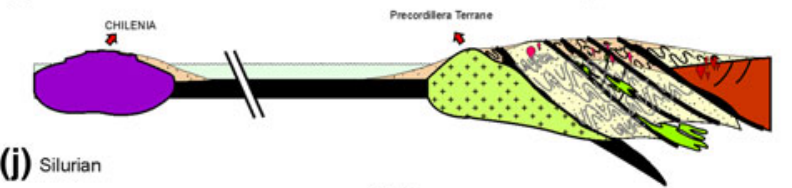

(j) Silurian



Fig. 7 Schematic evolution of the Eastern Sierras Pampeanas between 30 and $32^{\circ}$ SL from the Neoproterozoic to the Silurian. a Back-arc extension according to Escayola et al. (2007) and data from this paper, Table 2. Note that arc magmatism is developed in an inferred Arequipa derived block. Location of this margin close to the Kalahari craton is taken from Rapela et al. (2007). b Initial development of an accretionary prism along an active margin that started after the closure of the Adamastor ocean. Ages to constrain an older metamorphic overprint are taken from Sims et al. (1998) and Siegesmund et al. (2010). c Late Neoproterozoic to early Cambrian development of the Sierra Norte arc magmatism and concomitant deposition of accretionary prism sediments. d Deformation of the accretionary prism (Puncoviscana Formation equivalent) and cessation of arc magmatism. Ridge subduction hypothesis and ages for the magmatism are taken from Schwartz et al. (2008). Final closure of the orogen $\mathbf{e}$ is ascribed to the accretion of a slice of Mesoproterozoic basement that may correspond to the Western Sierras Pampeanas

Another hypothesis invokes a parautochthonous model, where the Cuyania Terrane (sedimentary sequence of the Precordillera of Argentina plus Grenville basement of the Western Sierras Pampeanas) migrated along a transform fault, from a position on the southern margin of West Gondwana (present coordinates) in the mid-Ordovician to its modern position outboard of the Famatina magmatic belt in Devonian time (Finney 2007 and references therein).

The interval between the end of the Pampean orogen and the initiation of the Famatinian subduction encompasses the uplift and erosion of the Pampean-related rocks that feed middle Cambrian foreland basins like the original basin of the PMC (which developed along the margin of the Pampean terrane) and the initiation of a new subduction along
Terrane or Pampia. The evidence for an Arequipa-Antofalla connection for this basement seems feasible (Casquet et al. 2008) but timing of accretion remains dubious. f Displacement of the Pampean belt from the original situation as an apron along the Kalahari margin to its final position facing the Río de la Plata Craton, which took place after ridge collision and during WSP accretion (Rapela et al. 2007). g Initiation of the subduction that migrated to the western border of the Pampean belt. Incipient development of extensional basins. Age constraints for the initiation of sedimentation are interpreted from the detrital data of Steenken et al. (2006), Siegesmund et al. (2010) and Drobe et al. (2009, 2010 this volume). h Accretion of the Precordillera Terrane. Age constraints for the Pringles Metamorphic Complex were taken from Steenken et al. (2006). Synorogenic deposition of Negro Peinado and Achavil Formations according to Collo et al. (2009). i Post-Famatinian margin of Gondwana. $\mathbf{j}$ Convergence of Chilenia based on Ramos (1988)

the western margin of the Pampean terrane. Collo et al. (2009) proposed that these foreland basins received contributions from the contemporaneous early Cambrian Pampean volcanism from the east (e.g. tuffs in the San Luis Formation) and from partially exhumed I-type granitoids. The first deformation and metamorphism in these basins was related to the onset of the Famatina subduction at around $500 \mathrm{Ma}$. Subsequently, an extensional ensialic back-arc regime was established. The initiation of granulitefacies metamorphism due to the transient anomaly associated with the 506-480 Ma mafic and ultramafic intrusions is contemporaneous or closely followed by the emplacement of crustal derived granitoids, such as the northern stock of the 491 Ma Paso del Rey granite and the 480-460 Ma OTS 
tonalite-granodiorite in the low-grade phyllites. The pronounced crustal signatures of both mafic and felsic rocks may indicate that the deeper exposed crustal levels of the PMC may show roots of the Famatinian arc. Delpino et al. (2007) proposed that a late compressional regime developed NNE trending shear zones which controlled the exhumation of the Ordovician complex.

Collo et al. (2009) suggested that the initiation of the Famatinian orogenic cycle could correspond to the Iruyic unconformity in NW Argentina. Extensional basins postdating the initiation of the Famatinan arc were developed along the entire margin of the Pampean terrane (Collo et al. 2009).

\section{Models for the Achalian Orogeny}

The (400-350 Ma) Achalian orogeny (or the Achalian cycle, Sims et al. 1997) resulted from the collision of the allochthonous Chilenia Terrane with Gondwana (Fig. 7) (Ramos et al. 1986; Ramos 1988; Sims et al. 1997, 1998; Davis et al. 1999; Quenardelle and Ramos 1999). This event roughly corresponds to the late to post-Famatinian events of the Famatinian cycle of Dalla Salda et al. (1998). The Achalian orogeny is a period of heterogeneous deformation due to crustal scale shear zones that may have resulted from the resumption of the convergence on the western margin of Gondwana (Siegesmund et al. 2004). Achalian granitoids intruded the older basement and are especially widespread in the Sierra de San Luis and the Sierras de Córdoba (Sims et al. 1997; Siegesmund et al. 2004; López de Luchi et al. 2007; Rapela et al. 2007). The large Devonian intrusions of the Sierras de Córdoba, i.e. the Achala and Cerro Aspero batholiths, show typical post-tectonic emplacement characteristics, like the highly discordant contact with the host rocks (Pinotti et al. 2006), suggesting that the block of the Sierras de Córdoba behaved as a rigid indenter during the accretion processes to the western outboard of Gondwana The voluminous Achalian granitic magmatism has raised much speculation regarding the underlying geodynamic causes (López de Luchi et al. 2007 and references therein). It was first discussed as post-tectonic in relation to the Famatinian cycle (Llambías et al. 1998; Dalla Salda et al. 1998) or as resulting from mafic underplating (López de Luchi 1996, López de Luchi et al. 2007). Alternatively, it can be proposed that this magmatism results from slab break-off during the late stages of the subduction that ended with the collision of Chilenia.

Acknowledgments We are grateful for the support by the German Science Foundation that funded our research projects in Argentina over the years (Grant $\mathrm{Si} 438 / 17$ and $\mathrm{Si} \mathrm{438/24)}$ ) as well as to the DAAD-ANTORCHAS programm. A. Steenken is also grateful for the DFG research scholarship (Ste 1036/1) and the Feodor-Lynen Fellowship V.3/FLF/1116298 from the Alexander von Humboldt
Foundation.M. López de Luchi thanks DAAD support through DAAD grants A/03/39422 and A/07/10368. Dr Zimmermann, Dr Basei and an anonymous reviewer are thanked for their helpful comments.

\section{References}

Aceñolaza F, Toselli AJ (1977) Esquema geológico de la Sierra de Ancasti, provincia de Catamarca. Acta Geológica Lilloana 14:233-256

Aceñolaza FG, Toselli AJ (1981) Geología del Noroeste Argentino. Publicación Especial de la Facultad de Ciencias Naturales, Universidad Nacional de Tucumán 1287:1-212

Anzil PA, Martino RD (2009) The megascopic and mesoscopic structure of La Cocha ultramafic body, Sierra Chica of Córdoba, Argentina. J S Am Earth Sci 28(4):398-406

Arndt NT, Goldstein SL (1987) Use and abuse of crust-formation ages. Geology 15(10):893-895

Astini RA, Dávila FM, Collo G (2008) Las discordancias Tilcárica e Irúyica en el noroeste argentino: una perspectiva regional. XVIII ${ }^{\circ}$. Congr Geol Argent Actas I:3-4

Báez MA, Bellos LI, Grosse P, Sardi FG (2005) Caracterización petrológica de la Sierra de Velasco. In: Dahlquist J, Rapela C, Baldo E (eds) Geología de la provincia de La Rioja-Precámbrico-Paleozoico Inferior. Asoc Geol Argent Spec Pub Serie D 8:123-130

Baldo E, Casquet C, Galindo C (1996) El metamorfismo de la Sierra Chica de Córdoba (Sierras Pampeanas) Argentina. Geogaceta 19:51-54

Balhburg H (1991) The Ordovician back-arc to foreland successor basin in the Argentinian-Chilean Puna: tectonosedimentary trends and sea-level changes. In: MacDonald DIM (ed) Sedimentation, tectonics, and eustasy. Spec Pub Inter Assoc Sedimentol 12:465-484

Bellos LI (2005) Geología y petrología del sector austral de la sierra de Velasco, al sur de los $29^{\circ} 44^{\prime} \mathrm{S}$, La Rioja, Argentina. In: Aceñolaza FG, Hünicken M, Toselli AJ, Aceñolaza GF (eds) Simposio Bodenbender: Trabajos completos. Serie de Correlación Geológica, $\mathrm{N}^{\circ}$ 19. INSUGEO (CONICET). San Miguel de Tucumán, 261-278

Bonalumi A, Martino R, Sfragulla J, Carignano C, Tauber A (2001) Hoja Geológica 3363-I. VILLA MARIA. (Memory and Geologic map). Instituto de Geología y Recursos Minerales -SEGEMAR, Buenos Aires

Boynton WV (1984) Geochemistry of the rare-earth elements: meteorite studies. In: Henderson P (ed) Rare earth element geochemistry. Elsevier, New York, pp 63-114

Büttner SH, Glodny J, Lucassen F, Wemmer K, Erdmann S, Handler R, Franz G (2005) Ordovician metamorphism and plutonism in the Sierra de Quilmes metamorphic complex: Implications for the tectonic setting of the northern Sierras Pampeanas (NW Argentina). Lithos 83(1-2):143-181

Casquet C, Baldo E, Pankhurst RJ, Rapela CW, Galindo C, Fanning CM, Saavedra J (2001) Involvement of the Argentine Precordillera Terrane in the Famatinian mobile belt: U-Pb SHRIMP and metamorphic evidence from the Sierra de Pie de Palo. Geology 29:703-706

Casquet C, Pankhurst RJ, Fanning CM, Baldo E, Galindo C, Rapela C, González-Casado JM, Dahlquist JA (2006) U-Pb SHRIMP zircon dating of Grenvillian metamorphism in Western Sierras Pampeanas (Argentina): correlation with the Arequipa Antofalla craton and constraints on the extent of the Precordillera Terrane. Gondwana Res 9:524-529

Casquet C, Pankhurst RJ, Rapela C, Galindo C, Fanning CM, Chiaradia M, Baldo E, González-Casado JM, Dahlquist JA 
(2008) The Maz terrane: a Mesoproterozoic domain in the western Sierras Pampeanas (Argentina) equivalent to the Arequipa-Antofalla block of southern Peru? implications for Western Gondwana margin evolution. Gondwana Res 13:163-175

Chew DM, Schaltegger U, Kosler J, Whitehouse MJ, Gutjahr M, Spikings RA, Miskovic A (2007) U-Pb geochronologic evidence for the evolution of the Gondwanan margin of the north-central Andes. GSA Bull 119:697-711

Collo G, Astini RA, Cardona A, Do Campo MD, Cordani U (2008) Edades de metamorfismo en las unidades con bajo grado de la región central del Famatina: la impronta del ciclo orogénico oclóyico (Ordovícico). Rev Geol Chil 35(2):191-213

Collo G, Astini RA, Cawood P, Buchan C, Pimentel M (2009) U-Pb detrital zircon ages and $\mathrm{Sm}-\mathrm{Nd}$ isotopic features in low-grade metasedimentary rocks of the Famatina belt: implications for late Neoproterozoic-Early Paleozoic evolution of the proto-Andean margin of Gondwana. J Geol Soc London 166:303-319

Dahlquist JA, Pankhurst RJ, Rapela CW, Galindo C, Alasino P, Fanning CM, Saavedra J, Baldo E (2008) New SHRIMP U-Pb data from the Famatina Complex: constraining Early-Mid Ordovician Famatinian magmatism in the Sierras Pampeanas, Argentina. Geol Acta 6(4):319-333

Dalla Salda LH, López de Luchi MG, Cingolani CA, Varela R (1998). Laurentia-Gondwana collision: the origin of the FamatinianAppalachian Orogenic Belt (a review). In: Pankhurst RJ, Rapela CW (eds) The Proto-Andean Margin of Gondwana. Geol Soc London Spec Pub 142:219-234

Davis JS, Roeske SM, Mc Clelland WC (1999) Closing the ocean between the Precordillera Terrane and Chilenia: Early Devonian ophiolite emplacement and deformation in the southwest Precordillera. In: Ramos VA, Keppie JD (eds) LaurentiaGondwana connections before Pangea. GSA Spec Pap 336:115-138

de Brodtkorb MK, Ostera H, Pezzutti N, Tassinari C (2005) Sm/Nd and K-Ar data from W-bearing amphibolites of Eastern Pampean Ranges, San Luis and Córdoba, Argentina. $\mathrm{V}^{\circ} \mathrm{S}$ Am Symp Isotope Geol, pp 478-482

Delpino SH, Bjerg EA, Ferracutti GR, Mogessie A (2007) Counterclockwise tectonometamorphic evolution of the Pringles Metamorphic Complex, Sierras Pampeanas of San Luis (Argentina). J S Am Earth Sci 23:147-175

Drobe M, López de Luchi MG, Steenken A, Frei R, Naumann R, Wemmer K, Siegesmund S (2009) Provenance of the Late Proterozoic to Early Cambrian metaclastic sediments of the Sierra de San Luis (Eastern Sierras Pampeanas) and Cordillera oriental, Argentina. J S Am Earth Sci 28:239-262

Drobe M, López de Luchi MG, Steenken A, Wemmer K, Naumann R, Frei R, Siegesmund S (2010) Geodynamic evolution of the Eastern Sierras Pampeanas (Central Argentina) based on geochemical, Sm-Nd, $\mathrm{Pb}-\mathrm{Pb}$ and SHRIMP data. doi:10.1007/ s00531-010-0593-3

Escayola M, Ramé G, Kraemer PE (1996) Caracterización y significado tectónico de las fajas ultramáficas de las Sierras Pampeans de Córdoba. XIII ${ }^{\circ}$ Congr Geol Argent Actas:421-438

Escayola MP, Pimentel MM, Armstrong R (2007) Neoproterozoic back-arc basin: sensitive high-resolution ion microprobe $\mathrm{U}-\mathrm{Pb}$ and $\mathrm{Sm}-\mathrm{Nd}$ isotopic evidence from the Eastern Pampean Ranges, Argentina. Geology 35:495-498

Fagiano M, Otamendi JE, Nullo F (2008) Los orógenos Pampeano y Famatiniano en la evolución de los complejos Monte Guazú y Achiras, Sierra de Comechingones, Córdoba. XVIII ${ }^{\circ}$ Congr Geol Argent, Jujuy, Actas:1008-1009

Finney SC (2007) The parautochthonous Gondwanan origin of the Cuyania (greater Precordillera) terrane of Argentina: a reevaluation of evidence used to support an allochthonous Laurentian origin. Geol Acta 5:127-158
Gaido MF (2003) Informe petrográfico de la hoja geológica Recreo 2966-IV, escala 1:250.000. Servicio Geológico Minero Argentino, delegación Córdoba, 12 pp

González PD, Sato AM, Llambías EJ, Basei MAS, Vlach SRF (2004) Early Paleozoic structural and metamorphic evolution of western Sierra de San Luis (Argentina), in relation to Cuyania Accretion. Gondwana Res 7:1157-1170

González PD, Sato AM, Llambías EJ, Petronilho LA (2009) Petrology and geochemistry of the banded iron formation in the Eastern Sierras Pampeanas of San Luis (Argentina): implications for the evolution of the Nogolí Metamorphic complex. J S Am Earth Sci 28(2):89-112

Gordillo CE (1984) Migmatitas cordieríticas de la sierra de Córdoba; condiciones físicas de la migmatización. Academia Nacional de Ciencias, Córdoba. Miscelánea 68:1-40

Gromet LP, Simpson C, Miro R, Whitmeyer SJ (2001) Apparent truncation and juxtaposition of Cambrian and Ordovician arcaccretionary complexes, Eastern Sierras Pampeanas, Argentina. Geol Soc Am Annual Meeting, Abstracts with Programs, vol 33. Boston, p A-155

Grosse P, Söllner F, Báez MA, Toselli AJ, Rossi JN, de la Rosa D (2008) Lower Carboniferous post-orogenic granites in centraleastern Sierra de Velasco, Sierras Pampeanas, Argentina: U-Pb monazite geochronology, geochemistry and $\mathrm{Sr}-\mathrm{Nd}$ isotopes. Inter J Earth Sci 98(5):1001-1025

Guereschi A, Martino RD (2008) Field and textural evidence of two migmatization events in the Sierras de Córdoba, Argentina. Gondwana Res 13:176-188

Hauzenberger C, Mogessie A, Hoinkes G, Felfernig A, Bjerg E, Kostadinoff J, Delpino S, Dimieri L (2001) Metamorphic evolution of the Sierras de San Luis, Argentina: Granulite facies metamorphism related to mafic intrusions. Mineral Petrol 71(1-2):95-126

Kay S, Orrell S, Abbruzzi JM (1996) Zircon and whole rock Nd-Pb isotopic evidence for a Grenville Age and a Laurentian origin for the basement of the Precordillera in Argentina. J Geol 104:637-648

Knüver M (1983) Dataciones radimétricas de rocas plutónicas y metamórficas. In: Aceñolaza FG, Miller H, Toselli J (eds) Geología de la sierra de Ancasti, Münstersche Forschungen zur Geologie und Pälaontologie, vol 59. Heft, Münster, pp 201-218

Kostadinoff J, Bjerg E, Delpino S, Dimieri L, Mogessie A, Hoinkes G, Hauzenberger C, Felfernig A (1998) Gravimetric and magnetometric anomalies in the Sierras Pampeanas of San Luis. Rev Asoc Geol Argent 53(4):549-552

Kraemer PE, Escayola MP, Martino RD (1995) Hipótesis sobre la evolución neoproterozoica de las Sierras Pampeanas de Córdoba (30 840-32 840S) Argentina. Rev Asoc Geol Argent 50(1-4):47-59

Kretz R (1983) Symbols for rock-forming minerals. Am Mineral 68:277-279

Krol MA, Simpson C (1999) Thermal history of the eastern Sierras Pampeanas accretionary prism rocks, constraints from ${ }^{40} \mathrm{Ar} /{ }^{39} \mathrm{Ar}$ mica data. GSA Abs Program 31(7):114-115

Lira R, Millone HA, Kirschbaum A, Moreno RS (1997) Calc-alkaline arc granitoid activity in the sierra Norte-Ambargasta ranges, central Argentina. J S Am Earth Sci 10:157-177

Llambías EJ, Sato AM, Ortiz Suárez A, Prozzi C (1998) The granitoids of the Sierra de San Luis. In: Pankhurst RJ, Rapela CW (eds) The Proto-Andean Margin of Gondwana. Geol Soc London Spec Pub 142:325-341

Llambías EJ, Gregori D, Basei MAS, Varela R, Prozzi C (2003) Ignimbritas riolíticas neoproterozoicas en la Sierra Norte de Córdoba: evidencia de un arco magmático temprano en el ciclo Pampeano? Rev Asoc Geol Argent 58(4):572-582

López de Luchi MG (1996) Enclaves en un batolito postectónico: petrología de los enclaves microgranulares del batolito de Renca. Rev Asoc Geol Argent 51(2):131-146 
López de Luchi MG, Favetto A, Pomposiello MC, Booker J (2005) Magnetotelluric evidence for the suture between the Río de la Plata and the Pampean cratons at $31^{\circ} 40^{\prime}$, Córdoba province, Argentina. VI Int Symp Andean Geodynamics, (ISAG 2005, Barcelona), Extended abstracts, pp 446-449

López de Luchi MG, Siegesmund S, Wemmer K, Steenken A, Naumann R (2007) Geochemical constraints on the petrogenesis of the Palaeozoic granitoids of the Sierra de San Luis, Sierras Pampeanas, Argentina. J S Am Earth Sci 24:138-166

Martínez Dopico CI, López de Luchi MG, Rapalini AE, Kleinhanns IC (2010) Distinguishing crustal segments in the North Patagonian Massif, Patagonia: an integrated perspective based on $\mathrm{Nd}$ systematics. J S Am Earth Sci doi:10.1016/j.jsames.2010.07.009 (in press)

Martino RD (2003) Las fajas de deformación dúctil de las Sierras Pampeanas de Córdoba: una reseña general. Rev Asoc Geol Argent 58:549-571

Martino R, Kraemer P, Escayola M, Giambastiani M, Arnosio M (1995) Transecta de las sierras Pampeanas de Córdoba a los $32^{\circ}$ LS. Rev Asoc Geol Argent 50:60-77

Miller H, Söllner F (2005) The Famatinian complex (NW Argentina): back-docking of an island arc or terrane accretion? Early Palaeozoic geodynamics at the western Gondwana margin. In: Vaughan APM, Leat PT, Pankhurst RJ (eds) Terrane Processes at the Margins of Gondwana, vol 246. Geol Soc London Spec Pub, pp 241-256

Millone HA, Tassinari CCG, Lira R, Poklepovic MF (2003) Age and neodymium isotope geochemistry of granitoids of the Sierra Norte-Ambargasta Batholith, Central Argentina, vol I. IV ${ }^{\circ} \mathrm{S}$ Am Symp Isotope Geol Actas, pp 617-620

Mutti DI (1987) Estudio geológico del Complejo Gabro-Peridotítico del área de Bosque Alegre, Córdoba. PhD Thesis, University of Buenos Aires $189 \mathrm{p}$ (unpublished)

Mutti DI (1992) El Complejo gabro-peridotítico de Bosque Alegre, Provincia de córdoba. Rev Asoc Geol Argent 47(2):153-167

Otamendi JE, Nullo FE, Patiño Douce AE, Fagiano MR (1998) Geology, mineralogy and geochemistry of syn-orogenic anatectic granites from the Achiras Complex, Córdoba; Argentina: some petrogenetic and geodynamic implications. J S Am Earth Sci 11(4):407-423

Otamendi JE, Fagiano MR, Nullo FE (2000) Geología y evolución metamórfica del Complejo Monte Guazú, sur de la sierra de Comechingones, provincia de Córdoba. Rev Asoc Geol Argent 55(3):265-279

Otamendi JE, Castellarini PA, Fagiano MR, Demichelis AH, Tibaldi AM (2004) Cambrian to Devonian geologic evolution of the Sierra de Comechingones, Eastern Sierras Pampeanas, Argentina: evidence for the developments and exhumation of continental crust on the Proto-Pacific Margin of Gondwana. Gondwana Res 7:1143-1155

Otamendi JE, Demichelis A, Tibaldi A, de la Rosa J (2006) Genesis of aluminous and intermediate granulites: a study case in the eastern Sierras Pampeanas, Argentina. Lithos 89:66-88

Pankhurst RJ, Rapela CW, Saavedra J, Baldo E, Dahlquist J, Pascua I, Fanning CM (1998) The Famatinian magmatic arc in the central Sierras Pampeanas: an Early to Mid-Ordovician continental arc on the Gondwana margin. In: Pankhurst RJ, Rapela CW (eds) The Proto-Andean Margin of Gondwana, vol 142. Geol Soc London Spec Pub, pp 343-367

Pankhurst RJ, Rapela CW, Fanning CM (2000) Age and origin of coeval TTG, I- and S-type granites in the Famatinian belt of NW Argentina. Royal Soc Edinburgh Trans Earth Sci 91:151-168

Pinotti LP, Coniglio JE, Esparza AM, D'Eramo FJ, Llambias EJ (2002) Nearly circular plutons emplaced at shallow crustal levels, Cerro Aspero batholith, Sierras Pampeanas de Córdoba, Argentina. J S Am Earth Sci 15:251-265
Pinotti L, Tubía JM, D’Eramo F, Vegas N, Sato AM, Coniglio J, Aranguren A (2006) Structural interplay between plutons during the construction of a batholith (Cerro Aspero batholith, Sierras de Córdoba, Argentina). J Struc Geol 28:834-849

Prozzi CR, Ramos G (1988) La Formación San Luis. In: Primeras Jornadas de trabajo de Sierras Pampeanas, San Luis Abstracts, p 1

Quenardelle S, Ramos VA (1999) Ordovician western Sierras Pampeanas magmatic belt: record of Precordillera accretion in Argentina. In: Ramos VA, Keppie JD (eds) Laurentia-Gondwana Connections before Pangea, vol 336. GSA, Spec Pap, pp 63-86

Ramos VA (1988) Late Proterozoic-early Paleozoic of South America: a collisional story. Episodes 11:168-174

Ramos VA (2008) The basement of the Central Andes: the Arequipa and related terranes. An Rev Earth Planet Sci 36:289-324

Ramos VA, Jordan TE, Allmendinger W, Mpodozis C, Kay SM, Cortés JM, Palma M (1986) Paleozoic terranes of the Central Argentine-Chilean Andes. Tectonics 5:855-880

Ramos VA, Escayola M, Mutti DI, Vujovich GI (2000) Proterozoicearly Paleozoic ophiolites of the Andean basement of southern South America. GSA Spec Pap 349:331-349

Rapela CW (2000) The Sierras Pampeanas of Argentina: Paleozoic building of the southern Proto-Andes. In: Cordani UG, Milani EJ, Thomas-Filho A, Campos DA (eds) Tectonic Evolution of South America. XXXI ${ }^{\circ}$ Inter Geol Congr, Río de Janeiro, pp 381-387

Rapela CW, Toselli AJ, Heaman L, Saavedra J (1990) Granite plutonism of the Sierras Pampeanas: an inner cordilleran Paleozoic arc in the southern Andes. GSA Spec Pap 241:77-90

Rapela CW, Pankhurst RJ, Bonalumi AA (1991) Edad y geoquímica del Pórfido Granítico de Oncán, sierra Norte de Córdoba, Sierras Pampeanas, Argentina. VI Congr Geol Chil, Viña del Mar, Actas 1:19-22

Rapela CW, Pankhurst RJ, Casquet C, Baldo E, Saavedra J, Galindo C, Fanning CM (1998) The Pampean Orogeny of the southern proto-Andes: Cambrian continental collision in the Sierras de Córdoba. In: Pankhurst RJ, Rapela CW (eds) The Proto-Andean margin of Gondwana, vol 142. Geol Soc London Spec Pub, pp 181-217

Rapela CW, Pankhurst RJ, Casquet C, Baldo E, Galindo C, Fanning CM, Saavedra J (2001) Ordovician metamorphism in the Sierras Pampeanas: new U-Pb SHRIMP ages in central-east Valle Fértil and the Velasco Batholith, vol 1. III ${ }^{\circ} \mathrm{S}$ Am Symp Isotope Geol, pp 616-619

Rapela CW, Baldo EG, Pankhurst RJ, Saavedra J (2002) Cordierite and Leucogranite Formation during Emplacement of Highly Peraluminous Magma: the El Pilón Granite Complex (Sierras Pampeanas, Argentina). J Petrol 43(6):1003-1028

Rapela CW, Fanning M, Baldo E, Dahlquist J, Pankhurst RJ, Murra J (2005) Coeval S- and I-type granites in the Sierra de Ancasti, Eastern Sierras Pampeanas, Argentina. In: Pankhurst RJ, Veiga G (eds) Gondwana 12: Geol Biol Herit Gondwana, Abstract, pp 307

Rapela CW, Pankhurst RJ, Casquet C, Fanning CM, Baldo EG, Gonzáles-Casado JM, Galindo C, Dahlquist J (2007) The Río de la Plata craton and the assembly of Gondwana. Earth Sci Rev 83:49-82

Rapela CW, Baldo EG, Pankhurst RJ, Fanning CM (2008) The Devonian Achala Batholith of the Sierras Pampeanas: F-rich aluminous A-type granites $\mathrm{VI}^{\circ} \mathrm{S}$, vol 1 . Am Symp Isotope Geol, p 104

Reissinger M (1983) Geología de la Sierra de Ancasti. Evolución geoquímica de las rocas plutónicas. Munster Forsch Geol Palaont 59:101-112

Rossi JN, Toselli AJ, Báez MA (2005) Evolución termobárica del ortogneis peraluminoso del noroeste de la sierra de Velasco, La Rioja. Rev Asoc Geol Argent 60(2):278-289 
Sato AM, González P, Sato K (2001). First indication of Mesoproterozoic age from the western basement of the Sierra de San Luis, Argentina, vol 1. III $^{\circ}$ S Am Symp Isotope Geol, pp 64-67

Sato AM, González PD, Llambías EJ (2003) Evolution of the Famatinian orogen in the Sierra de San Luis: arc magmatism, deformation, and low to high-grade metamorphism. Rev Asoc Geol Argent 58:487-504

Schwartz JJ, Gromet LP (2004) Provenance of a late Proterozoicearly Cambrian basin, Sierras de Córdoba, Argentina. Precambr Res 129:1-21

Schwartz JJ, Gromet LP, Miro R (2008) Timing and duration of the calc-alkaline arc of the Pampean orogeny: implications for the late Neoproterozoic to Cambrian Evolution of Western Gondwana. J Geol 116:39-61

Shirey SB, Hanson GN (1986) Mantle heterogeneity and crustal recycling in Archean granite-greenstone belts: Evidence from Nd-isotopes and trace elements in the Rainy Lake area, Superior province, Ontario, Canada. Geochim Cosmochim Acta 50:2631-2651

Siegesmund S, Steenken A, López de Luchi MG, Wemmer K (2004) The Las Chacras-Potrerillos Batholith: structural evidences on its emplacement and timing of the intrusion. Inter $\mathrm{J}$ Earth Sci 93:23-43

Siegesmund S, Steenken A, Martino R, Wemmer K, López de Luchi MG, Frei R, Presniakov S, Guereschi A (2010) Time constraints on the tectonic evolution of the Eastern Sierras Pampeanas (Central Argentina). Int $\mathrm{J}$ Earth Sci. doi:10.1007/s00531009-0471-z

Sims JP, Skirrow RG, Stuart-Smith PG, Lyons P (1997) Informe geológico y metalogenético de las Sierras de San Luis y Comechingones (provincias de San Luis y Córdoba), 1:250000. Anales 28. IGRM, SEGEMAR, Buenos Aires, pp 1-148

Sims JP, Ireland TR, Camacho A, Lyons P, Pieters PE, Skirrow RG, Stuart-Smith PG, Miró R (1998) U-Pb, Th-Pb and $\mathrm{Ar}-\mathrm{Ar}$ geochronology form the southern Sierras Pampeanas: implication for the Palaeozoic tectonic evolution of the western Gondwana margin. In: Pankhurst RJ, Rapela CW (eds) The Proto-Andean Margin of Gondwana, vol 142. Geol Soc London Spec Pub, pp 259-281

Spear FS, Kohn MJ, Cheney JT (1999) P-T paths from anatectic pelites. Contrib Mineral Petrol 134:17-32

Steenken A, López de Luchi MG, Siegesmund S, Wemmer K, Pawlig S (2004) Crustal provenance and cooling of the basement complexes of the Sierra de San Luis: an insight into the tectonic history of the proto-Andean margin of Gondwana. Gondwana Res 7(4):1171-1195

Steenken A, López de Luchi MG, Siegesmund S, Wemmer K (2005) The thermal impact of the accommodation of mafic melts within the central basement complex of the Sierra de San Luis: constraints from numeric modeling. $\mathrm{XVI}^{\circ}$ Congr Geol Argent, La Plata. Actas 1:889-896

Steenken A, Siegesmund S, López de Luchi MG, Frei R, Wemmer K (2006) Neoproterozoic to early Palaeozoic events in the Sierra de San Luis: implications for the Famatinian geodynamics in the Eastern Sierras Pampeanas (Argentina). J Geol Soc London 163:965-982

Steenken A, Siegesmund S, Wemmer K, López de Luchi MG (2008) Time constraints on the Famatinian and Achalian structural evolution of the basement of the Sierra de San Luis (Eastern Sierras Pampeanas, Argentina). J S Am Earth Sci 25(3):336-358

Steenken A, Wemmer K, Martino RD, López de Luchi MG, Guereschi A, Siegesmund S (2010) Post-Pampean cooling and the uplift of the Sierras Pampeanas in the west of Córdoba (Central Argentina). N Jb Geol Paläont Abh 256:235-255

Stuart-Smith PG, Camacho A, Sims JP, Skirrow RG, Lyons P, Pieters PE, Black LP (1999) Uranium-lead dating of felsic magmatic cycles in the southern Sierras Pampeanas, Argentina: implications for the tectonic development of the proto-Andean Gondwana margin. In: Ramos VA, Keppie JD (eds) LaurentiaGondwana Connections before Pangea, vol 336. GSA Spec Pap, pp 87-114

Thomas W, Astini R (2003) Ordovician accretion of the Argentine Precordillera terrane to Gondwana: a review. J S Am Earth Sci 16:67-79

Tibaldi AM, Otamendi JE, Gromet LP, Demichelis AH (2008) Suya Taco and Sol de Mayo mafic complexes from the Eastern Sierras Pampeanas, Argentina: Evidence for the emplacement of primitive OIB-like magmas into deep crustal levels at a late stage of the Pampean orogeny. J S Am Earth Sci 26:172-187

Toselli AJ (1990) Metamorfismo del Ciclo Pampeano. In: Aceñolaza FG, Miller H, Toselli AJ (eds) El Ciclo Pampeano en el Noroeste Argentino. Universidad Nacional de Tucumán, Argentina, vol 4. Serie Correlación Geológica, pp 81-197

Toselli AJ, Rossi de Toselli JN (1990) Plutonismo de la Formación Puncoviscana. In: Aceñolaza FG, Miller H, Toselli AJ (eds) El Ciclo Pampeano en el Noroeste Argentino. Universidad Nacional de Tucumán, Argentina, vol 4. Serie Correlación Geológica, pp 221-227

Toselli AJ, Miller H, Rossi JN, Aceñolaza FG, Söllner F (2005) The Sierra de Velasco, NW Argentina, an example for polyphase magmatism at the margin of Gondwana. XIX ${ }^{\circ}$ Colloquium on Latin American Geosciences. Terra Nostra. Schriften der GeoUnion Alfred-Wegener-Stiftung 05/1:125-126 (Potsdam)

Trindade RIF, D'Agrella-Filho MS, Epof I, Brito Neves BB (2006) Paleomagnetism of early Cambrian Itabaiana mafic dikes (NE Brazil) and the final assembly of Gondwana. Earth Planet Sci Lett 244:361-377

Verdecchia SO, Baldo E, Benedetto L, Borghi R (2007) The first shelly faunas from metamorphic rocks of the Sierras Pampeanas (La Cébila Formation), Sierra de Ambato, Argentina): age and paleogeographic implications. Ameghiniana 44:493-498

Vielzeuf D, Montel JM (1994) Partial melting of metagreywackes. Part I. Fluid-absent experiments and phase relationships. Contrib Mineral Petrol 117:375-393

von Gosen W, Prozzi C (1998) Structural evolution of the Sierra de San Luis (Eastern Sierras Pampeanas, Argentina): implications for the Proto-Andean margin of Gondwana. In: Pankhurst RJ, Rapela CW (eds) The Proto-Andean Margin of Gondwana, vol 142. Geol Soc London Spec Pub, pp 235-258

Vujovich GI, Ostera HA (2003) Evidence of the Pampean cycle in the basement of the northwestern sector of the Sierra de San Luis. Rev Asoc Geol Argent 58:541-548

Vujovich GI, van Staal CR, Davis W (2004) Age Constraints on the tectonic evolution and provenance of the Pie de Palo Complex, Cuyania Composite Terrane, and the Famatinian Orogeny in the Sierra de Pie de Palo, San Juan, Argentina. Gondwana Res 7:1041-1056

Willner A (1983) Evolución metamórfica. In: Aceñolaza FG, Miller H, Toselli A (eds) Geología de la Sierra de Ancasti, vol 59. Münst Forsch Geol Paläont, pp 189-200

Wu FY, Jahn BM, Wilde SA, Lo C, Yui TF, Lin Q, Ge WC, Sun DY (2003) Highly fractionated I-type granites in NE China (II): isotopic geochemistry and implications for crustal growth in the Phanerozoic. Lithos 67:191-204 